\title{
Integração Regional e Convergência Econômica Real: Lições da Experiência Europeia
}

\section{Regional Integration Agreements and Real Economic Convergence: Lessons from the European Experience}

\author{
Giuliano Contento de Oliveira* \\ Simone da Silva de Deos** \\ Paulo José Whitaker Wolf* *
}

\begin{abstract}
Resumo: Ao longo dos últimos cinquenta anos, o projeto de integração regional europeu tornou-se progressivamente mais complexo e passou a contar com um número cada vez maior de países membros, bastante diferentes do ponto de vista estrutural. $\mathrm{O}$ artigo buscou avaliar os efeitos desse ousado projeto sobre as desigualdades socioeconômicas preexistentes entre esses países. A análise de indicadores selecionados mostrou que houve indícios de convergência econômica real entre 1993 e 2008. No entanto, a crise europeia representou uma inflexão nessa trajetória. Sustenta-se que a criação de políticas e instituições comuns, capazes de auxiliar os países membros mais atrasados a superar as estruturas que caracterizam o subdesenvolvimento, decerto contribuiu para esse processo. Entre elas, destaca-se a política regional, ou de coesão, da União Europeia. Contudo, o arranjo macroeconômico a que se submeteram os países europeus nos últimos anos limitou consideravelmente a sua capacidade de estimular o crescimento do produto, da renda e do emprego, impondo, assim, importantes limites ao processo de convergência entre eles.
\end{abstract}

Palavras-chave: Integração regional. Convergência econômica real. União Europeia.

Abstract: Over the last fifty years, the European regional integration project has become increasingly complex and has counted on an increasingly number of

* $\quad$ Professor doutor do Instituto de Economia da Universidade Estadual de Campinas (IE/Unicamp). Pesquisador do Centro de Estudos de Relações Econômicas Internacionais (Ceri) do IE/Unicamp. E-mail: giuliano@eco.unicamp.br

* $\quad$ Professora doutora do Instituto de Economia da Universidade Estadual de Campinas (IE/Unicamp). Pesquisadora do Centro de Estudos de Relações Econômicas Internacionais (Ceri) do IE/ Unicamp. E-mail: simonedd@uol.com.br

*** Mestrando em Economia no Instituto de Economia da Universidade Estadual de Campinas (IE/ Unicamp). Pesquisador do Centro de Estudos de Relações Econômicas Internacionais (Ceri) do IE/Unicamp.E-mail: paulowwolf@gmail.com 
member-countries which are very different from the structural point of view. The article sought to evaluate the effects of this audacious project on socioeconomic inequalities pre-existing between these countries. The analysis of selected indicators showed that there were evidences of real economic convergence between 1993 and 2008. However, the European crisis represented a shift in this trend. It is argued that the creation of common policies and institutions in order to assist countries that are lagging behind to overcome the structures which characterize underdevelopment certainly contributed to this process. This is the case of the European Union's regional or cohesion policy. Nevertheless, the macroeconomic framework to which the European countries were submitted in recent years considerably restricted its ability to stimulate the growth of output, income and employment, therefore imposing important limits to the process of convergence between them.

Keywords: Regional integration. Real economic convergence. European Union.

JEL Classification: F50; F59; F33; F34.

\section{Introdução}

Desde o pós-guerra, o mundo assistiu a um crescimento sem precedentes de acordos de integração regional. Embora tenham ocorrido em todos os continentes, foi na Europa que assumiram contornos mais ambiciosos. Os europeus transferiram poderes soberanos para um conjunto de instituições comuns, que passaram a conceber e implementar políticas em áreas estratégicas. Esse modo de fazer as coisas diferia muito de outras experiências, nas quais prevaleceu o intergovernamentalismo em detrimento do supranacionalismo. Nesse caso, os governos dos países participantes mantêm sua autonomia e se limitam a tomar decisões com base em negociações entre si.

É realmente surpreendente que, em apenas cinquenta anos, tenha sido possível unir por laços tão estreitos países de um continente que havia sido dilacerado por duas grandes guerras, intercaladas por uma grande depressão, e que depois se tornou a expressão concreta de um mundo dividido entre o capitalismo, de um lado, e o comunismo, do outro. De fato, o projeto de integração regional europeu nasceu e cresceu como um exemplo de cooperação entre os países que o compõem. Uma questão fundamental, entretanto, é saber se essa cooperação produziu resultados no que se refere à redução das assimetrias existentes entre eles.

Nessa perspectiva, este trabalho tem o objetivo de investigar se o projeto de integração regional europeu contribuiu para reduzir as desigualdades socioeconômicas existentes entre países estruturalmente diferentes. A análise de indicadores selecionados sugere ter havido um processo de convergência econômica real 
entre esses países entre 1993 e 2008: a renda per capita dos países mais pobres da União Europeia cresceu mais rapidamente do que a dos países mais ricos, e a variabilidade das rendas per capita de todos os países do bloco diminuiu sensivelmente. Além disso, a taxa de desemprego caiu e o perfil das relações comerciais intrarregionais tornou-se menos assimétrico, ao menos no que se refere à composição de suas pautas de exportação. Argumenta-se que as políticas e instituições comuns orientadas para o desenvolvimento, com destaque para a política regional da União Europeia, cumpriram papel muito importante para a ocorrência desse fenômeno durante o período indicado.

A experiência europeia sugere que um projeto de integração regional não deve se limitar à eliminação dos obstáculos na circulação de mercadorias, serviços, pessoas e capitais entre os países participantes, mas, sim, viabilizar a criação de políticas e instituições comuns destinadas a superar os atrasos econômico e social que caracterizam os países da periferia, complementando a ação dos estados nacionais. $\mathrm{O}$ projeto de integração regional europeu foi o primeiro a criar instrumentos dessa natureza. Embora não se possa atribuir a eles a responsabilidade exclusiva pelo processo de convergência que, como apontam os indicadores selecionados, aconteceu entre os países europeus nas últimas duas décadas, é provável que esses instrumentos tenham desempenhado aí um papel relevante. Esse é o caso da política regional da União Europeia, a qual patrocina ações destinadas à transformação das regiões mais pobres do bloco por meio dos fundos estruturais e de coesão.

Deve-se destacar, contudo, que o processo de redução das desigualdades existentes entre os países europeus foi abruptamente interrompido a partir de 2008. Isso se deve, em grande medida, aos limites impostos à política macroeconômica no âmbito do projeto de integração regional. De fato, ao proceder com a união monetária, os países europeus renunciaram ao controle sobre a política macroeconômica em favor de um arranjo institucional cuja preocupação central é a convergência de variáveis nominais, tais como as taxas de inflação, de juros e de câmbio, além do déficit público e da dívida pública. Não bastasse isso, diante da crise europeia, esses países foram pressionados pelo mercado a se submeter a um regime de política macroeconômica que em nada contribui para a recuperação do crescimento do produto, da renda e do emprego.

Este trabalho está, então, organizado da seguinte forma: na próxima seção discute-se a especificidade do projeto de integração regional europeu e os possíveis efeitos de um projeto dessa natureza sobre as desigualdades socioeconômicas existentes entre os países participantes. Em seguida serão avaliados indicadores selecionados, buscando analisar se houve ou não um processo de convergência econômica real, no período de 1993 a 2010, entre os países que compõem a União Europeia. Após são apontadas algumas lições da experiência europeia, tendo-se 
como referência os resultados obtidos na seção anterior. Em especial, será destacado, de um lado, o papel da política regional da União Europeia e, de outro, os limites impostos à política macroeconômica no bloco. Para finalizar, seguem-se, então, algumas considerações à guisa de conclusão.

\section{Integração Regional: a Experiência Europeia e Abordagens Teóricas}

Nesta seção serão discutidos o processo de construção do projeto de integração regional europeu e os principais traços que o caracterizam e o diferenciam de outras experiências de caráter semelhante. Serão consideradas, também, algumas das contribuições teóricas a respeito dos efeitos da constituição de uma área integrada sobre as assimetrias econômicas e sociais existentes entre os países que a compõem.

\subsection{Integração Regional: a Experiência Europeia}

Foi no contexto adverso do pós-guerra que os europeus deram os primeiros passos em direção àquele que se tornaria o mais ousado projeto de integração regional da história. Em 1951, por meio do Tratado de Paris, criou-se a Comunidade Europeia do Carvão e do Aço, por meio da qual uma autoridade supranacional seria responsável por controlar recursos essenciais à reconstrução das economias afetadas pelo maior conflito armado de todos os tempos. Em 1957, o Tratado de Roma criou a Comunidade Econômica Europeia, uma união aduaneira (caracterizada, portanto, pela redução significativa das barreiras tarifárias e não tarifárias ao comércio de mercadorias entre os países participantes e pela criação de uma política comercial comum em relação aos países não participantes), e a Comunidade Europeia de Energia Atômica, que aumentou a cooperação entre os países membros no âmbito da energia nuclear. Em 1965, as três comunidades passaram a partilhar as mesmas instituições executivas, legislativas e judiciárias no âmbito da Comunidade Europeia, criada pelo Tratado de Bruxelas. Em 1985, após um período de avanços modestos, iniciaram-se os preparativos para a criação de um mercado comum e se decidiu que todos os obstáculos remanescentes à livre circulação de mercadorias, serviços, pessoas e capitais entre os países membros deveriam ser eliminados em um prazo máximo de sete anos. O Ato Único Europeu, de 1986, assegurou as mudanças institucionais necessárias para isso. Em 1992, o Tratado de Maastricht criou a União Europeia. O objetivo era avançar não apenas na cooperação no âmbito econômico, mas também nos âmbitos social e político. O Tratado de Maastricht foi modificado pelo Tratado de Amsterdã, em 1997, pelo Tratado de Nice, em 2001, e pelo Tratado de Lisboa, em 2007.

O que distingue a experiência europeia de outras iniciativas no resto do mundo é a opção pela transferência de poderes soberanos dos países membros para 
um conjunto de instituições supranacionais ao invés da negociação entre governos que preservam grande parte de sua autonomia. Essas instituições supranacionais, por sua vez, tornam-se responsáveis por conceber e implementar um conjunto de políticas comuns, isto é, ações conjuntas em áreas estratégicas. Grande parte dessas instituições e políticas é financiada pelos recursos do orçamento comunitário, os quais provêm de impostos sobre o valor adicionado e sobre produtos importados de países terceiros, recolhidos pelos governos e transferidos para os cofres comunitários, bem como de contribuições de cada país membro de acordo com a importância relativa de sua economia. Essa opção pelo supranacionalismo em detrimento do intergovernamentalismo evidenciou-se desde a Comunidade Europeia do Carvão e do Aço e atingiu o seu auge com a conclusão da união monetária e a criação da zona do euro, no final dos anos 1990.

De fato, uma característica importante do projeto de integração regional europeu, a saber, a ideia de uma moeda comum, estava presente já no Tratado de Roma, embora tenha demorado a se tornar realidade. Com o fim da ordem de Bretton Woods, os países europeus - mais vulneráveis às variações no valor relativo de suas moedas, uma vez que haviam reduzido as barreiras do comércio existentes entre si - criaram um sistema de bandas cambiais, o que daria origem ao sistema conhecido como "serpente". ${ }^{1}$ Esse sistema mostrou-se insustentável diante das pressões sobre as taxas de câmbio no contexto de estagflação que se seguiu ao primeiro choque do petróleo. Alguns países foram, inclusive, forçados a abandoná-lo. Em função disso, a "serpente" foi substituída pelo Sistema Monetário Europeu, em 1979. Com isso, o sistema de bandas cambiais, então bastante enfraquecido, foi restaurado, e uma unidade de referência, a Unidade Monetária Europeia, foi criada. Mais uma vez, vários países encontraram dificuldades em lidar com as pressões sobre as taxas de câmbio, em especial depois que os alemães realizaram uma elevação histórica da taxa de juros para conter as pressões inflacionárias decorrentes do esforço de (re)integração da antiga Alemanha Oriental no início dos anos 1990. Nem mesmo a ampliação dos limites para a flutuação das taxas de câmbio foi suficiente para evitar que alguns países abandonassem o acordo.

O Sistema Monetário Europeu arrastou-se até 1992, quando, sob forte pressão dos franceses, o Tratado de Maastricht deu início ao processo de criação de uma união monetária. A desintegração do bloco comunista no leste europeu e o anseio alemão pela reunificação redesenharam o "xadrez político" no continente, no fim dos anos 1980 e início dos anos 1990. Nessa perspectiva, a França viu na

\footnotetext{
A chamada "serpente europeia" (European snake) foi criada no âmbito do Acordo Smithsoniano realizado no início da década de 1970 e destinado a defender o padrão monetário internacional do pós-Segunda Guerra (dólar-ouro), oriundo dos Acordos de Bretton Woods. A "serpente" correspondeu à ampliação das margens de flutuação das moedas europeias dos países que aderiram ao acordo, para $2,25 \%$, ante a banda estreita de $1 \%$ estabelecida no sistema de Bretton Woods. Para mais detalhes, ver Eichengreen (2000, p. 185, 202, 204, 208, 214, 221, 212).
} 
moeda única uma forma de ancorar a Alemanha ao projeto de integração regional europeu, fazendo disso condição para a reunificação (OLIVEIRA; DEOS, 2012). Os alemães concordaram em renunciar ao poderoso marco, símbolo de sua prosperidade no pós-guerra, desde que fossem eles os responsáveis por ditar o perfil da união monetária. Sem resistir, os franceses, então, consentiram.

Esse processo ocorreu em três etapas. Na primeira foram asseguradas as precondições para uma união monetária, isto é, a plena mobilidade de capitais e a coordenação das políticas macroeconômicas dos países membros. Na segunda foi criado o Instituto Monetário Europeu, composto pelos presidentes dos bancos centrais nacionais. Além disso, decidiu-se que os países que desejassem adotar a moeda comum deveriam atender aos seguintes critérios (os chamados critérios de convergência): a) as taxas de inflação não poderiam ultrapassar em mais de 1,5\% a média das três economias que tivessem as taxas de inflação mais baixas; b) as taxas de juros de longo prazo não poderiam variar mais de $2 \%$ em relação à média das taxas das três economias que tivessem as taxas de juros de longo prazo mais baixas; c) os déficits públicos deveriam ser inferiores a 3\% do PIB; d) as dívidas públicas não poderiam exceder $60 \%$ do PIB; e) quanto às taxas de câmbio, as economias deveriam respeitar as margens de flutuação definidas pelo Sistema Monetário Europeu. Por fim, na terceira etapa, as taxas de câmbio foram fixadas irrevogavelmente em relação à unidade monetária europeia, que passou a se chamar euro. Além disso, o Instituto Monetário Europeu foi substituído por uma instituição supranacional, o Banco Central Europeu (BCE). Com os bancos centrais nacionais, a instituição compõe o chamado Sistema Europeu de Bancos Centrais (ARESTIS; SAWYER, 2011). O euro foi formalmente criado em 1999, passando a circular dois anos depois.

O BCE tornou-se responsável pelas políticas monetária e cambial de todos os países que adotaram o euro. A instituição deveria atuar de forma independente, livre de qualquer influência, seja das demais instituições da União Europeia, seja dos governos nacionais. O objetivo, com isso, seria assegurar o seu comprometimento com a estabilidade do nível de preços. A política fiscal, por sua vez, permaneceu sob responsabilidade dos governos nacionais. No entanto, mesmo assim, está sujeita às restrições do Pacto de Estabilidade e Crescimento, proposto em 1995 pelo então ministro das finanças alemão, Theo Waigel, e aprovado pelos demais países europeus dois anos depois, em 1997, após várias rodadas de negociação. Segundo o acordo, os governos deveriam evitar um déficit público superior a 3\% do PIB ao longo do ciclo econômico. Se porventura ultrapassassem esse limite e não introduzissem as medidas corretivas sugeridas pelo Conselho para Questões Econômicas e Financeiras da União Europeia dentro de um determinado prazo, estariam sujeitos a sanções, incluindo o pagamento de multas (ARESTIS et al., 2003). 
Ao mesmo tempo em que se tornava mais complexo, o projeto de integração regional europeu passou a contar com um número cada vez maior de países membros. Esse número cresceu de seis (Alemanha, Bélgica, França, Itália, Luxemburgo e Países Baixos), em 1951, para nove (com a entrada de Dinamarca, Irlanda e Reino Unido), em 1973, dez (com a inclusão da Grécia), em 1981, 12 (com o ingresso de Espanha e Portugal), em 1986, 15 (com a entrada de Áustria, Finlândia e Suécia), em 1995, 25 (com a inclusão de Chipre, Eslováquia, Eslovênia, Estônia, Hungria, Letônia, Lituânia, Malta, Polônia e República Tcheca), em 2004, 27 (com o ingresso de Bulgária e Romênia), em 2007, e 28 (com a adesão da Croácia), em 2013. Atualmente, 17 países da União Europeia adotam o euro como moeda oficial, passando a compor a chamada zona do euro. Dentre os dez países restantes, alguns ainda não se qualificaram para adotá-lo, enquanto outros optaram voluntariamente por conservar suas antigas moedas.

É evidente, entretanto, que esses países aderiram ao projeto de integração regional em condições muito diferentes, de modo que o ingresso, primeiro, da Irlanda e dos países da Europa meridional, e, depois, das Ilhas Mediterrâneas (Chipre e Malta) e dos países da Europa oriental, aumentou consideravelmente as desigualdades socioeconômicas existentes no bloco fundado pelos países da Europa setentrional. Nesse contexto, uma questão central que se coloca é em que medida o aprofundamento do projeto de integração regional foi acompanhado pela redução das desigualdades socioeconômicas existentes entre os países europeus. Ou se, ao contrário, ele contribuiu para aumentar ainda mais essas desigualdades. Antes de verificar o que ocorreu na prática, convém recuperar o que a teoria econômica tem a oferecer sobre o assunto.

\subsection{Integração Regional: a Abordagem Convencional e as Abordagens Alternativas}

Não há, no âmbito da teoria econômica, um consenso acerca dos efeitos da constituição de uma área integrada sobre as desigualdades socioeconômicas dos países participantes. De acordo com a teoria econômica ortodoxa, a abertura das fronteiras viabilizaria um processo de equalização de variáveis reais, como o produto ou renda per capita, de todos os países participantes, independentemente de suas condições iniciais. Em outras palavras, a integração regional produziria convergência econômica real entre esses países. Deve-se observar, entretanto, que para a teoria econômica ortodoxa, um projeto de integração regional constitui o que se poderia chamar de second best choice. Isso porque a melhor alternativa seria assegurar a eliminação dos obstáculos existentes à livre circulação de mercadorias, serviços, pessoas e capitais em escala global, ao invés de restringi-la a um grupo restrito de países ou regiões.

Segundo a teoria neoclássica do comércio internacional, considerada a partir do modelo de Heckscher-Ohlin, deverá haver a equalização dos preços de fatores 
de todos os países que estiverem comercializando entre si segundo o princípio das vantagens comparativas: esses países deverão exportar aquelas mercadorias cuja produção exige a utilização intensiva do fator relativamente abundante e barato e importar aquelas mercadorias cuja produção exige a utilização intensiva do fator relativamente escasso e caro. Essa especialização levará a um aumento do preço do fator relativamente abundante e barato e a uma redução do preço do fator relativamente escasso e caro. Ademais, uma vez que tal equalização de preços de fatores é um caminho possível para a equalização dos níveis de renda, pode-se dizer que o modelo de Heckscher-Ohlin prevê convergência econômica real entre esses países. De acordo com a abordagem neoclássica, essa conclusão é perfeitamente aplicável a um contexto de integração regional, uma vez que as relações comerciais entre os países participantes são fomentadas por meio da eliminação das barreiras tarifárias e não tarifárias existentes entre eles (SALVATORE, 2007; BEN-DAVID, 2007).

Por sua vez, a teoria neoclássica do crescimento econômico, representada pelo modelo de Solow, prevê que economias com parâmetros semelhantes (como taxa de poupança e taxa de crescimento populacional) deverão sempre convergir para um mesmo estoque de capital e renda por trabalhador. No caso do modelo com progresso técnico, no longo prazo, esse estoque de capital e renda por trabalhador deverá, ainda, crescer à mesma taxa para todos os países, dessa vez independentemente dos seus parâmetros, uma vez que o progresso técnico, que motiva esse crescimento, é como o "maná que cai do céu", algo que se difunde perfeitamente entre todas as economias, independentemente de como e onde foi gerado (se nas regiões mais ricas ou nas mais pobres). Segundo essa perspectiva, espera-se que em um contexto de integração regional, o processo de convergência seja acelerado, desde que seja assegurada a redução das barreiras à mobilidade de fatores. Isso porque o capital deverá fluir das regiões mais ricas, onde ele é abundante e barato, para as regiões mais pobres, onde ele é escasso e caro. Da mesma forma, o trabalho deverá fluir das regiões mais pobres, onde ele é abundante e barato, para as regiões mais ricas, onde ele é escasso e caro. O aumento do estoque de capital e a redução do número de trabalhadores nas regiões mais pobres, por sua vez, aceleram o seu crescimento econômico (JONES, 2000; RAY, 1998; TONDL, 2001a).

A questão é que tanto a teoria neoclássica do comércio internacional quanto a teoria neoclássica do crescimento econômico se sustentam em pressupostos bastante restritivos. Elas supõem que não existem quaisquer obstáculos à livre-circulação de mercadorias e fatores produtivos, que o trabalho e o capital são qualitativamente iguais em todas as economias, que a tecnologia se difunde perfeitamente entre elas e, o que é mais importante, que o sistema de preços relativos opera de modo a permitir que os agentes, agindo livremente e de forma racional, tomem decisões capazes de levar as economias à melhor alocação possível dos fatores de 
produção (ARMSTRONG; TAYLOR, 2000; TONDL, 2001a). Mas, e quando se admite que o sistema econômico não caminha inexoravelmente para uma situação de equilíbrio e que, nesse contexto, outros elementos, para além do sistema de preços relativos, podem influenciar as decisões dos agentes? Nesse caso, os benefícios da integração regional, no que se refere à redução das desigualdades entre os países participantes, são menos óbvios. Mais que isso, a convergência econômica real pode deixar de ser a regra para se tornar a exceção.

Algumas abordagens consideram a existência das chamadas falhas de mercado. A teoria da nova geografia econômica, por exemplo, demonstra que, uma vez que seja possível atender à demanda de outras regiões por meio de exportações, dado a abertura das fronteiras, as empresas preferirão concentrar sua produção em algumas poucas regiões, a fim de auferir economias de escala. Essas regiões serão aquelas que apresentarem maiores mercados e/ou facilidades, como infraestrutura adequada, por exemplo. Ocorre, porém, que à medida que uma região começa a atrair empresas, surgem incentivos para que outras empresas também se estabeleçam ali. Isso porque existem economias de aglomeração. No limite, portanto, poucas regiões deverão concentrar a maior parte da produção, de modo que haverá um centro próspero e uma periferia decadente. Dessa forma, admite-se que a existência das falhas de mercado poderá levar à divergência, ao invés da convergência, entre as regiões envolvidas no projeto de integração regional. Isso porque essas falhas de mercado, embora não sejam precificadas, também são capazes de influenciar as decisões dos agentes (KRUGMAN, 1991a, 1991b, 1998, 2011).

Já no âmbito das teorias alternativas à visão convencional, outro fator capaz de influenciar a decisão dos atores seria a moeda, tal como demonstra a teoria pós-keynesiana. Em um contexto de forte incerteza, os detentores de riqueza preferirão reter ativos mais líquidos. Quando isso acontece, entretanto, esses atores reduzem os seus gastos, sendo que a insuficiência de demanda gera a queda do produto, da renda e do emprego. Para os pós-keynesianos, as diferenças estruturais entre os países do centro e da periferia implicam distintos graus de confiança e, assim, de vulnerabilidade a mudanças no estado geral das expectativas. Por si só isso constitui um problema, pois implica a possibilidade de que as flutuações da demanda e dos preços-chave da economia sejam mais acentuadas nas regiões menos desenvolvidas vis-à-vis às mais desenvolvidas.

Ocorre, porém, que em um contexto de integração regional em que as restrições aos fluxos internacionais de capitais são drasticamente reduzidas, a situação pode se tornar ainda mais grave. Em geral, diante do aumento da incerteza e, consequentemente, do grau de preferência pela liquidez dos agentes, os recursos financeiros tendem a ser redirecionados para os países desenvolvidos em busca de um refúgio seguro. A possibilidade dessa "fuga para a qualidade", por sua vez, 
constitui uma fonte adicional de instabilidade e contribui para que o atraso das regiões mais pobres se perpetue (DOW, 1982; CHICK; DOW, 1988; AMADO, 1998; AMADO; SILVA, 2000).

Por fim, a teoria estruturalista concebe o subdesenvolvimento como uma situação ou condição decorrente da forma como se organizam determinadas economias. Em geral, as economias subdesenvolvidas são caracterizadas por um sistema produtivo heterogêneo e pouco diversificado, sendo os setores menos intensivos em tecnologia o seu motor propulsor, consequência de um processo de divisão internacional do trabalho orientado pelo princípio das vantagens comparativas, segundo o qual à periferia caberia produzir mercadorias intensivas em trabalho e recursos naturais, as quais seriam exportadas ao centro em troca de mercadorias intensivas em capital. Tais economias tendem a ser menos produtivas, gerando menores níveis de produto e renda, além de piores empregos, bem como mais vulneráveis às mudanças na demanda e nos preços internacionais.

Nessa perspectiva, a superação do subdesenvolvimento passaria necessariamente pela industrialização. O fato é que a integração regional poderia ser um aliado importante nesse processo, uma vez que viabilizaria a ampliação dos mercados para os produtos industriais exigentes em escala, criaria novas oportunidades de exportação e permitiria que os países periféricos importassem em condições mais favoráveis aqueles bens que ainda não tivessem condições de produzir internamente. Entretanto, é pouco provável que a indústria nascente da periferia tenha condições de competir com a indústria consolidada do centro, o que poderia levá-la à renúncia do esforço de industrialização e, assim, preservar o status quo. Por essa razão, entende-se que um tratamento igual aos desiguais, em um contexto de integração regional, tende a se perpetuar ou mesmo a ampliar as desigualdades existentes entre os países participantes (BIELSCHOWSKY, 2000; AMADO; MOLLO, 2004; MEDEIROS, 2008).

\section{Projeto de Integração Regional Europev e o Processo de Convergência Econômica Real}

A coesão econômica e social sempre figurou como um objetivo central do projeto de integração regional europeu. ${ }^{2}$ A fim de verificar se esse objetivo foi cumprido, dispõe-se de vários indicadores, os quais captam diferentes dimensões das condições de vida em um determinado conjunto de países ou regiões. Para os objetivos desse artigo, serão considerados os seguintes indicadores: a renda

\footnotetext{
$2 \quad$ De acordo com o Artigo 130 do Tratado de Roma apud El-Agraa (2011, p.421): "In order to promote its overall harmonious development, the Community shall develop and pursue its actions leading to strengthening of its economic and social cohesion. In particular, the Community shall aim at reducing disparities between the levels of development of the various regions and the backwardness of the least favored regions or islands, including rural areas."
} 
per capita, a taxa de desemprego e o perfil das relações comerciais intrarregionais para o período de 1993 a 2010. Serão considerados, também, os 27 países que compunham a União Europeia até o ingresso da Croácia, em 2013. Tendo-se em vista não apenas a sua localização geográfica, mas também as suas características econômicas e sociais, esses países foram classificados em três grupos, a saber: a Europa setentrional (Alemanha, Áustria, Bélgica, Dinamarca, Finlândia, França, Itália, Luxemburgo, Países Baixos, Reino Unido e Suécia), a Europa meridional (Grécia, Espanha e Portugal) mais a Irlanda, e a Europa oriental (Bulgária, Eslováquia, Eslovênia, Estônia, Hungria, Letônia, Lituânia, Polônia, República Tcheca e Romênia) mais as Ilhas Mediterrâneas (Chipre e Malta). ${ }^{3}$

O Gráfico 1 apresenta a renda per capita de cada país membro em relação à renda per capita média de todos os países membros do bloco europeu, de modo que UE $(27)=100$. Observa-se que os europeus setentrionais são muito mais ricos que os europeus meridionais e que ambos são mais ricos que os orientais. Mesmo assim, há indícios de que a diferença entre o norte e o sul e entre o oeste e o leste se reduziu nas últimas duas décadas. Embora a renda per capita média da União Europeia tenha crescido ininterruptamente até 2008, a renda per capita da maioria dos países da Europa meridional (mais a Irlanda) e oriental (mais Chipre e Malta) cresceu mais que essa média, de modo que a relação entre a renda per capita desses países em relação à renda per capita média cresceu. $\mathrm{O}$ mesmo não se verificou para a maioria dos países da Europa setentrional, cuja renda per capita cresceu menos que a média, razão pela qual a relação entre a renda per capita desses países em comparação à renda per capita média caiu. Destaque para os desempenhos da Finlândia, na Europa setentrional, para o da Irlanda e para o da maioria dos países da Europa oriental, como a Eslováquia, a Eslovênia, os países bálticos (Estônia, Letônia e Lituânia) e a Polônia, que apresentaram um aumento da renda per capita em relação à renda per capita média da União Europeia de, aproximadamente, dez pontos percentuais durante o período de 1993 a 2008.

Não obstante, o processo de convergência das rendas per capita cessou a partir de 2008, em razão do aprofundamento da crise na Europa. Todos os países foram atingidos, ainda que em diferentes graus, o que pode ser constatado pela

3 Embora a Irlanda não esteja localizada na Europa meridional, do ponto de vista das variáveis consideradas nesse trabalho, ela partilha de muitas das características dos países dessa região. Quando aderiram ao projeto de integração regional europeu, eles eram bastante atrasados em relação aos seus vizinhos. Não por outra razão, a Irlanda e os países da Europa meridional foram, durante muito tempo, os principais beneficiados pelas iniciativas comunitárias destinadas a reduzir as desigualdades socioeconômicas existentes entre os países europeus, absorvendo parcelas expressivas dos Fundos Estruturais e do Fundo de Coesão. No vocabulário de Bruxelas, esses países eram chamados de "Cohesion Countries". Por sua vez, as Ilhas Mediterrâneas, ou seja, Chipre e Malta, foram alocadas entre os países da Europa oriental porque, assim como eles, aderiram ao projeto de integração regional europeu apenas na última década. 
queda da renda per capita média da União Europeia. A periferia europeia ${ }^{4}$ foi a principal prejudicada: a renda per capita dessas economias caiu mais que a média, ao passo que a das economias centrais caiu menos que a média. Por isso, a relação entre a renda per capita da Irlanda e da maioria dos países da Europa meridional e oriental e a renda per capita média caiu. Já no caso da maioria dos países da Europa setentrional essa relação cresceu.

Gráfico 1 - Renda per capita (UE 27 = 100): 1993 a 2010 (anos selecionados)

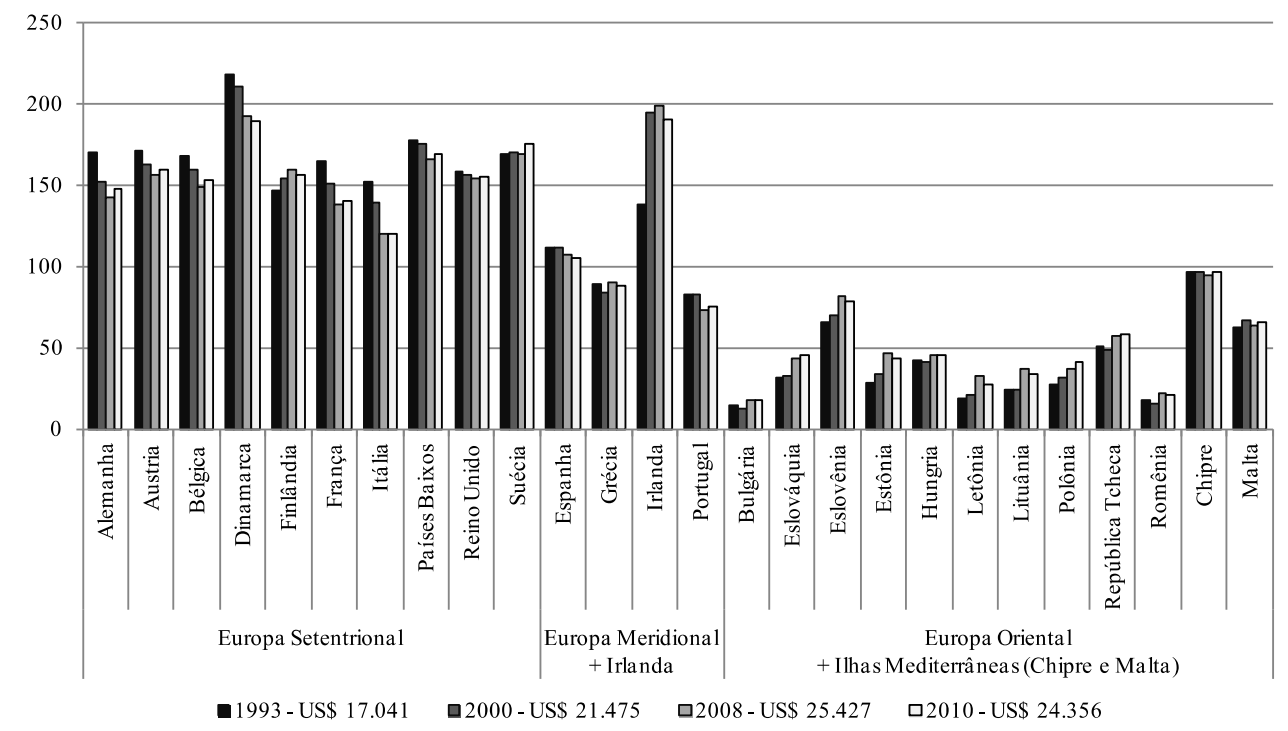

Fonte: Elaboração própria a partir de United Nations Conference on Trade and Development (2013). Nota: Cálculo a partir da renda per capita em US\$ (preços de 2005). Luxemburgo foi excluído pelo seu tamanho reduzido.

A tendência à convergência das rendas per capita durante a maior parte do período considerado também pode ser verificada a partir do Gráfico 2. No eixo horizontal tem-se o logaritmo natural da renda per capita em 1993 e no eixo vertical tem-se a taxa anual de crescimento média da renda per capita entre 1993 e 2010. Cada ponto representa um país da União Europeia. A linha de tendência que aproxima esses pontos tem a forma padrão $Y=A+\beta . X$ (em que $Y$ é a taxa de crescimento média e $X$ é o logaritmo natural da renda per capita em 1993).

Na presença da chamada convergência beta, o coeficiente $\beta$ deve ser diferente de zero e negativo. Esse parece ser o caso europeu, o que significa que os países que mais cresceram entre 1993 e 2010 foram os que possuíam a menor renda per capita em 1993, ao passo que os países que menos cresceram foram aqueles que possuíam a maior renda per capita no início do período considerado.

Integram o centro os países da Europa setentrional e, a periferia, os países da Europa meridional (mais a Irlanda) e oriental (mais Chipre e Malta). 
Novamente, o destaque cabe à Finlândia e à Suécia (no limite superior do terceiro quadrante) na Europa setentrional, à Irlanda (no segundo quadrante) e à maioria dos países da Europa oriental (no primeiro quadrante). Deve-se observar que no primeiro quadrante estão os países mais pobres que cresceram em ritmo mais acelerado, no segundo quadrante, os países mais ricos que cresceram mais rapidamente e, finalmente, no terceiro quadrante, os países mais ricos que cresceram em ritmo inferior à média.

Gráfico 2 - Convergência beta (1993 a 2010)

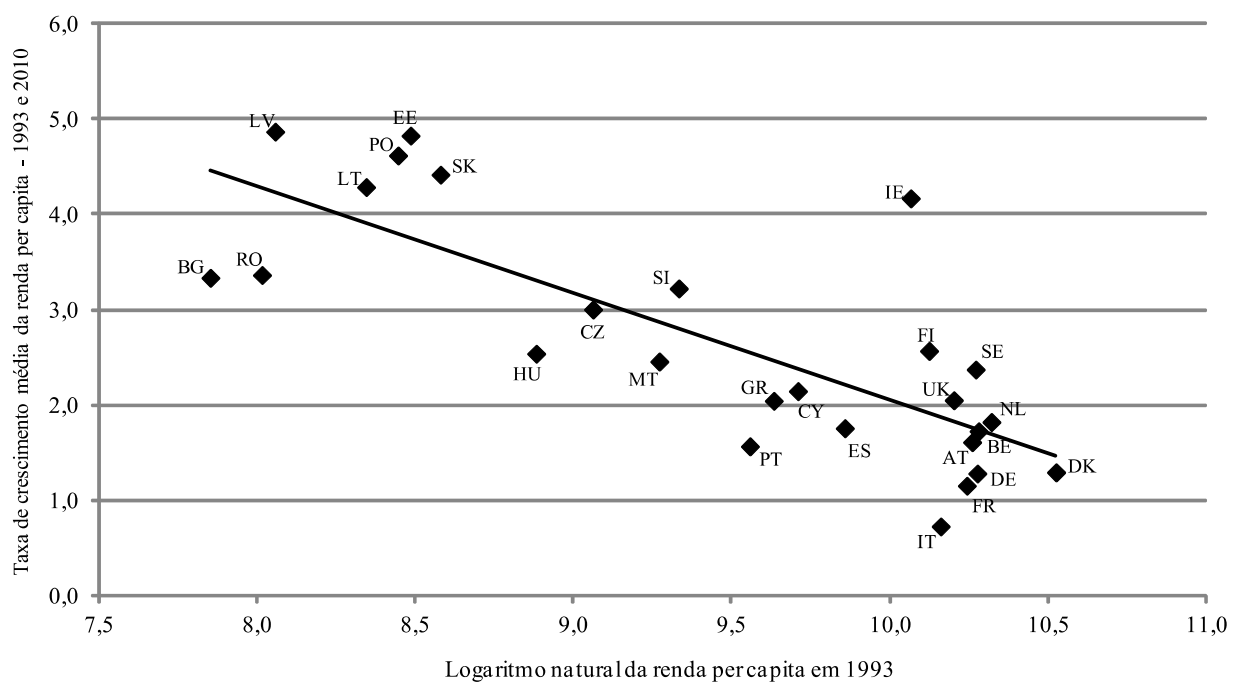

Fonte: Elaboração própria a partir de United Nations Conference on Trade and Development (2013). Nota: Cálculo a partir da renda per capita em US\$ (preços de 2005). Reta de tendência: $Y=13,3$ $-1,125$. $X$. Coeficiente de determinação: $R^{2}=0,6075$. Luxemburgo foi excluído pelo seu tamanho reduzido.

Se a crise global e, particularmente, europeia, não tivesse reduzido de forma tão expressiva as taxas de crescimento das rendas per capita a partir de 2008 , sobretudo no caso da Irlanda e dos países da Europa meridional e oriental, a inclinação da reta de tendência seria ainda maior. ${ }^{5}$ Vale dizer que os países mais pobres teriam crescido ainda mais rapidamente e o processo de convergência das rendas per capita teria sido mais significativo.

Por sua vez, o Gráfico 3 demonstra a evolução do chamado coeficiente de variação, uma medida de dispersão dada pela razão entre o desvio-padrão das rendas per capita dos países da União Europeia e a média para cada ano considerado. ${ }^{6}$

Isto é, o coeficiente $\beta$ teria sido mais elevado em módulo.

Um desvio-padrão elevado em relação a uma média baixa é mais relevante que um desviopadrão elevado em relação a uma média também elevada. Daí a opção por tal indicador, ao invés do desvio-padrão simples. 


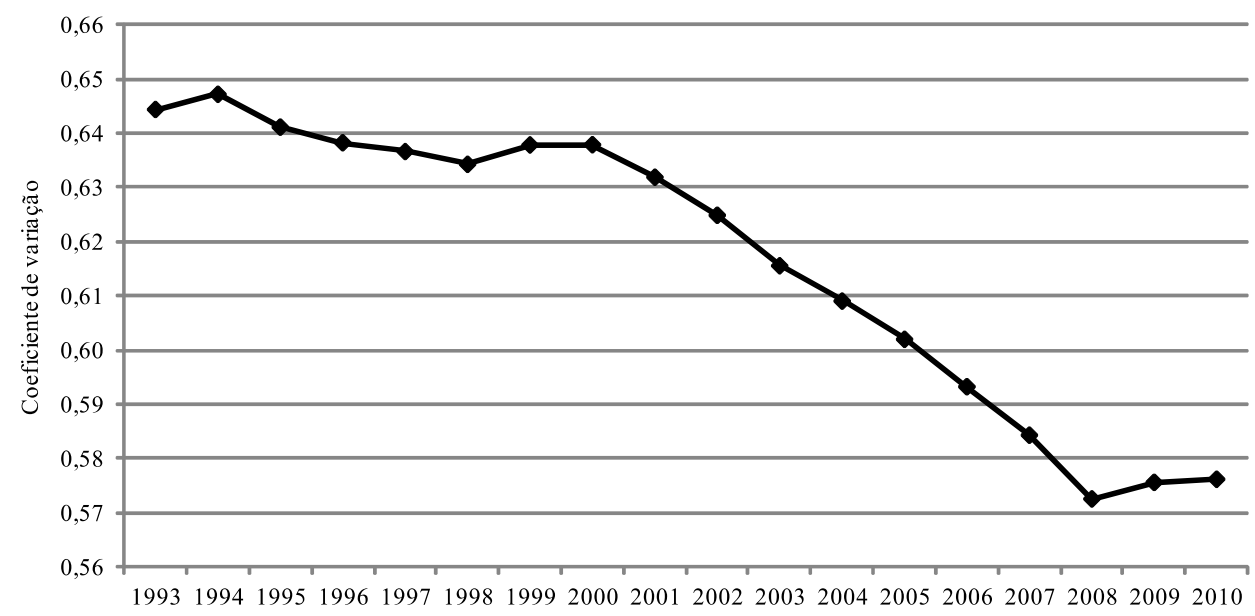

Fonte: Elaboração própria a partir de United Nations Conference on Trade and Development (2013). Nota: Cálculo a partir da renda per capita em US\$ (preços de 2005). Luxemburgo foi excluído pelo seu tamanho reduzido.

Na presença da chamada convergência sigma, o coeficiente de variação deve apresentar redução, o que indicaria uma diminuição da dispersão (ou da variabilidade) das rendas per capita dos países ou regiões considerados e, assim, a formação de um espaço mais coeso. Isso ocorreu no caso europeu, sobretudo a partir de 2000. Já o aumento da dispersão das rendas per capita durante a segunda metade da década de 1990 deveu-se às dificuldades enfrentadas pela maioria dos países da Europa oriental, que foram bastante prejudicados pelas crises da Ásia, em 1997 e, principalmente, da Rússia, em 1998. É preciso lembrar que a maioria desses países ainda possuía laços estreitos com Moscou. Sendo assim, quando a Rússia entrou em crise, arrastou consigo os países que pertenceram à antiga União Soviética, ou que permaneceram sob sua influência durante quase meio século.

Nota-se ainda que, em razão da crise, a dispersão das rendas per capita deixou de cair em 2008, permaneceu praticamente inalterada em 2009 e voltou a subir em 2010. Isso mostra, mais uma vez, que a crise comprometeu a continuidade do processo de convergência das rendas per capita até então em curso na União Europeia.

A taxa de desemprego também constitui um dos principais indicadores das condições de vida. O Gráfico 4 apresenta a proporção entre o número de pessoas que não estão trabalhando e a população economicamente ativa em anos selecionados entre 1993 e 2010. 
Gráfico 4 - Taxa de desemprego na UE (\%): 1993 a 2010 (anos selecionados)

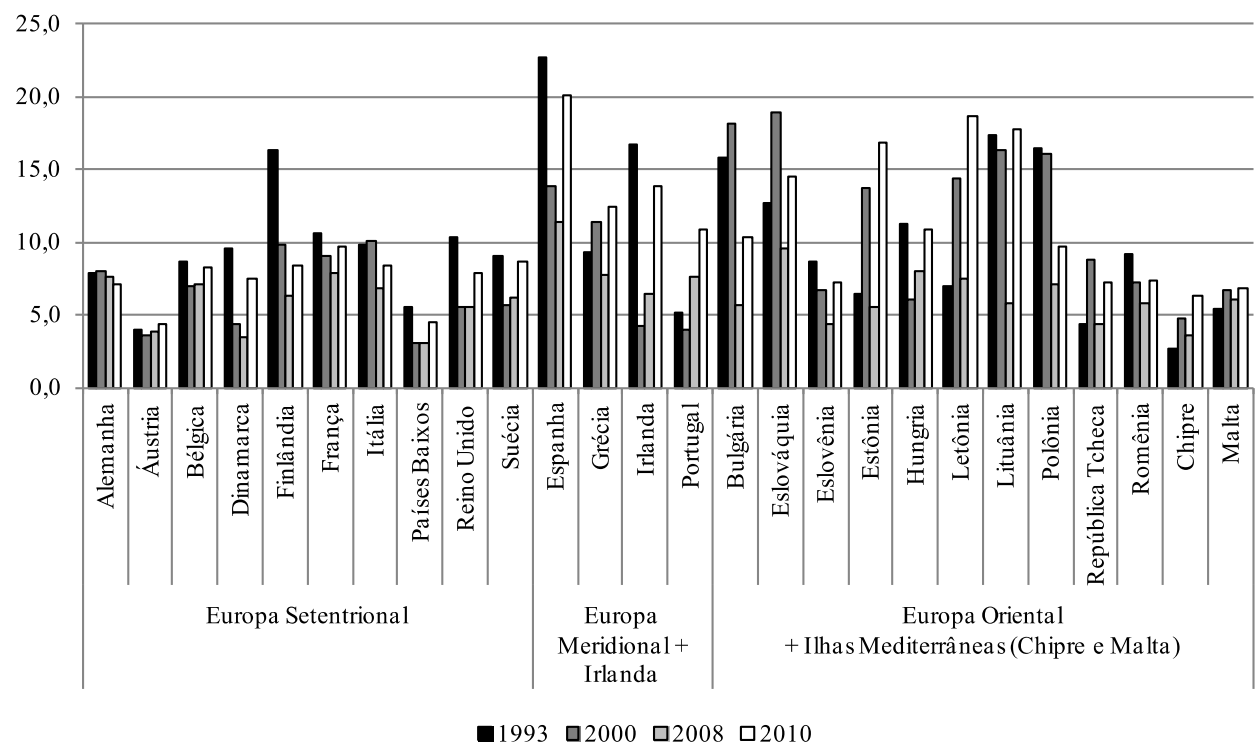

Fonte: Elaboração própria a partir de International Monetary Fund (2013).

Nota: Luxemburgo foi excluído pelo seu tamanho reduzido.

A expressiva maioria dos países membros da União Europeia encerrou 2008 com uma taxa de desemprego inferior à registrada em 1993. Em muitos casos, inclusive nos países da periferia do bloco, essa queda foi muito pronunciada. Nessas regiões, a maior parte das vagas foi criada no setor de serviços. Além disso, segundo estudos da Comissão Europeia (2010, 2007, 2004, 2001, 1996), essa queda beneficiou também os jovens com menos de 25 anos, tradicionalmente, a faixa etária que mais sofre com a falta de oportunidades no continente. Destaque para a Dinamarca e a Finlândia, na Europa setentrional, para a Espanha, na Europa meridional, e a Irlanda, bem como para os países da Europa oriental, como Bulgária, Eslováquia, os países bálticos (Estônia, Letônia, Lituânia), Polônia e Romênia, que chegaram a apresentar uma queda da taxa de desemprego de aproximadamente dez pontos percentuais durante o período considerado.

A crise, contudo, alterou radicalmente esse quadro. A taxa de desemprego cresceu vertiginosamente a partir de 2008 , alcançando, e em alguns casos superando, os níveis verificados em 1993. A situação é particularmente grave nos casos da Irlanda e dos países da Europa meridional e oriental, ainda que as Ilhas Mediterrâneas e os países da Europa setentrional também não tenham permanecido incólumes. Mostra-se, pois, pertinente a observação da Comissão Europeia (2010, 2007, 2004, 2001, 1996), de que a taxa de desemprego tende a ser resistente à queda, mas não à alta na União Europeia. Afinal, para muitos países do bloco, apenas dois anos foram suficientes para reverter os avanços de quase duas décadas. 
Por fim, resta a análise do perfil das relações comerciais intrarregionais. Com a eliminação gradual de todas as barreiras tarifárias e não tarifárias no comércio intrarregional, os países europeus acabaram por se tornar cada vez mais os principais parceiros comerciais uns dos outros. A importância dos demais países membros para as exportações e importações de cada país membro do bloco praticamente dobrou nos últimos cinquenta anos ${ }^{7}$. Além disso, a constituição e o aprofundamento do processo de integração regional na Europa resultaram em profundas transformações nas pautas de exportação desses países. A esse respeito, a Tabela 1 apresenta a composição das pautas de exportação dos países membros da União Europeia em relação aos demais países do bloco a partir de categorias de produtos definidas pela Conferência das Nações Unidas para o Comércio e o Desenvolvimento (UNCTAD, sigla em inglês): mercadorias de baixo valor agregado (commodities primárias, bens intensivos em trabalho e recursos naturais e bens de baixa intensidade tecnológica) e mercadorias de alto valor agregado (bens de média e alta intensidade tecnológica).

Como se sabe, o que uma economia vende ao exterior é um indicador não apenas de sua inserção externa, como também de seu dinamismo interno. Em geral, quanto maior a participação de produtos mais sofisticados na pauta de exportação, mais complexa é a estrutura produtiva do país, maior a sua capacidade de gerar mais e melhores empregos e menos passiva e/ou vulnerável a sua inserção externa. $^{8}$

No início da década de 1990, a Europa setentrional exportava produtos mais sofisticados e importava produtos de baixo valor agregado, ao passo que a maioria dos países da Europa meridional e oriental exportava mercadorias de baixo valor agregado e importava mercadorias mais sofisticadas. Entre os dois grupos de países, estabelecia-se, portanto, o que se costuma chamar de comércio norte-sul, isto é, a troca de commodities primárias, bens intensivos em trabalho e recursos naturais e bens de baixa intensidade tecnológica por bens de média e alta inten-

$7 \quad$ A parcela das exportações totais de cada país-membro que é destinada aos demais países-membros do bloco passou de 33\%, em 1957, para 55\%, em 1974; 53\%, em 1981; 61\%, em 1986; 62\%, em 1995; 63\% em 2000; e 69\%, em 2005. Já a parcela das importações totais de cada país-membro que é proveniente dos demais países-membros do bloco passou de 30\%, em 1957, para 51\% em 1974 e 1981; 59\%, em 1986; 67\%, em 1995; 62\%, em 2000; e 69\%, em 2005.

8 Um aumento da participação de produtos de alto valor agregado nas pautas de exportação da periferia não precisa ter, como contrapartida, uma redução da participação dos produtos de alto valor agregado nas pautas de importação. Os próprios países centrais apresentam uma pauta de importação com elevada participação dos produtos de alto valor agregado. Em razão de um sistema de produção cada vez mais globalizado e, consequentemente, da fragmentação das cadeias de valor entre diferentes países e regiões, o chamado comércio intraindústria tende a ocupar, cada vez mais, um papel de destaque no comércio internacional. Para mais informações sobre essa questão, ver Wolf (2011). 
sidade tecnológica. ${ }^{9}$ Mas há indícios de que esse perfil, altamente assimétrico, foi reduzido ao longo das duas últimas décadas, embora a crise tenha significado um retrocesso também nesse âmbito. Efetivamente, houve um aumento expressivo da participação de produtos mais sofisticados na pauta de exportação dos países da periferia do bloco. Destaque para a Irlanda, para a Grécia e Portugal (na Europa meridional), para o Chipre e para a maioria dos países da Europa oriental, como Eslováquia, Eslovênia, Estônia, Letônia, Polônia, República Tcheca, Romênia e, principalmente, Hungria. Todos esses países chegaram a apresentar um aumento de aproximadamente 20 pontos percentuais na participação dos produtos de alto valor agregado em suas pautas de exportação durante o período considerado.

Troca de minérios, metais, produtos agrícolas e pecuários (cereais, frutas, legumes e verduras, além de carnes, leite e ovos), alimentos processados, bebidas, têxteis, vestuário, calçados, entre outros, por produtos químicos, farmacêuticos e eletroeletrônicos, além de instrumentos de precisão, máquinas e equipamentos, veículos, embarcações e aeronaves etc. 
Tabela 1 - Exportação de mercadorias de baixo e alto valor agregado em relação ao total exportado para a União Europeia (\%): 1992 a 2008 (anos selecionados)

\begin{tabular}{|c|c|c|c|c|c|c|c|}
\hline \multirow{2}{*}{ Regiões / Países } & \multicolumn{3}{|c|}{ Baixo valor agregado } & \multirow{2}{*}{ Regiões / Países } & \multicolumn{3}{|c|}{ Alto valor agregado } \\
\hline & 1992 & 2000 & 2008 & & 1992 & 2000 & 2008 \\
\hline \multicolumn{8}{|c|}{ Europa Setentrional } \\
\hline Alemanha & 31,6 & 25,3 & 28,1 & Alemanha & 64,0 & 62,8 & 59,3 \\
\hline Áustria & 44,6 & 38,9 & 41,7 & Áustria & 51,1 & 47,4 & 49,0 \\
\hline Bélgica/Luxemburgo & 44,3 & 38,6 & 35,5 & Bélgica/Luxemburgo & 47,1 & 52,2 & 52,4 \\
\hline Dinamarca & 56,0 & 46,9 & 44,1 & Dinamarca & 36,4 & 39,6 & 37,2 \\
\hline Finlândia & 63,5 & 48,9 & 43,7 & Finlândia & 30,6 & 45,8 & 44,3 \\
\hline França & 42,1 & 32,9 & 34,7 & França & 53,5 & 60,5 & 55,3 \\
\hline País es Baixos & 49,0 & 35,6 & 32,7 & Países Baixos & 38,1 & 49,8 & 44,1 \\
\hline Itália & 49,1 & 44,8 & 43,3 & Itália & 45,9 & 51,1 & 48,8 \\
\hline Reino Unido & 31,9 & 22,0 & 25,3 & Reino Unido & 56,6 & 61,4 & 50,1 \\
\hline Suécia & 46,6 & 35,1 & 37,3 & Suécia & 47,5 & 52,4 & 46,1 \\
\hline \multicolumn{8}{|c|}{ Europa Meridional + Irlanda } \\
\hline Espanha & 39,7 & 38,7 & 41,2 & Espanha & 56,0 & 57,5 & 55,5 \\
\hline Grécia & 84,4 & 65,8 & 58,4 & Grécia & 8,0 & 21,2 & 29,0 \\
\hline Irlanda & 40,3 & 15 & 17,8 & Irlanda & 48,0 & 72,3 & 73,1 \\
\hline Portugal & 69,9 & 55,3 & 52,9 & Portugal & 27,3 & 42,7 & 40,4 \\
\hline \multicolumn{8}{|c|}{ Europa Oriental + Ilhas Mediterrâneas (Chipre e Malta) } \\
\hline Bulgária & 67,0 & 75,1 & 66,4 & Bulgária & 28,9 & 18,1 & 24,8 \\
\hline Es lováquia & 57,8 & 42,6 & 32,7 & Eslováquia & 34,7 & 48,7 & 58,6 \\
\hline Eslovênia & 56,3 & 46,0 & 38,1 & Eslovênia & 39,5 & 52,2 & 58,4 \\
\hline Estônia & 64,0 & 48,7 & 47,0 & Estônia & 29,3 & 47,3 & 38,7 \\
\hline Hungria & 66,1 & 28,1 & 24,5 & Hungria & 29,0 & 68,1 & 72,3 \\
\hline Letônia & 83,0 & 83,9 & 63,1 & Letônia & 11,5 & 12,6 & 27,8 \\
\hline Lituânia & 64,7 & 53,9 & 40,5 & Lituânia & 28,7 & 22,5 & 28,4 \\
\hline Polônia & 65,5 & 52,4 & 43,3 & Polônia & 23,4 & 40,7 & 50,6 \\
\hline República Tcheca & 55,0 & 39,9 & 31,3 & República Tcheca & 34,6 & 54,4 & 62,4 \\
\hline Romênia & 68,5 & 72,9 & 49,0 & Romênia & 18,0 & 22,5 & 43,6 \\
\hline Chipre & 81,5 & 57,2 & 42,5 & Chipre & 16,8 & 39,3 & 43,9 \\
\hline Malta & 22,0 & 33,1 & 18,3 & Malta & 75,0 & 61,6 & 75,7 \\
\hline
\end{tabular}

Fonte: Elaboração própria a partir de UN Comtrade (2013).

Nota: Para alguns países, não há dados disponíveis para os anos de 1992 e 2008. Nesse caso, ajustes precisaram ser feitos. Para República Tcheca, Eslováquia e Letônia, os dados de 1992 correspondem aos de 1994. Para Bulgária e Estônia, de 1996. Para Espanha, os dados de 2008 correspondem aos de 2006 . Além disso, a diferença entre $100 \%$ e a soma das mercadorias de baixo valor agregado e de alto valor agregado exportadas/importadas corresponde às mercadorias não classificadas.

Contudo, é preciso considerar que, algumas vezes, esse aumento pode não corresponder a uma mudança efetiva na estrutura produtiva dos países, os quais podem ser apenas responsáveis pela montagem do produto final a partir de componentes importados de outras regiões, tendo-se em vista as diferentes dotações e preços de fatores produtivos. Uma forma aproximada de verificar se esse tem sido o caso da periferia europeia é considerar a evolução do valor adicionado pela manufatura nesses países em relação ao valor adicionado total. Espera-se que um aumento da participação dos produtos de alto valor agregado nas pautas de exportação dos países membros tenha como contrapartida um aumento do valor 
adicionado pela manufatura desses países. ${ }^{10}$ Em muitos dos países da União Europeia, isso de fato ocorreu. ${ }^{11}$

Assim, embora as diferenças entre a Europa setentrional, de um lado, e a Europa meridional (mais a Irlanda) e oriental (mais Chipre e Malta), do outro, permaneçam expressivas, há indícios de que elas se reduziram nas últimas duas décadas, ainda que em ritmos distintos. A análise dos indicadores selecionados sugere que, considerando o período em tela, a renda per capita dos países mais pobres cresceu mais rapidamente que a dos países mais ricos (convergência beta) e que a variabilidade das rendas per capita de todos os países da União Europeia diminuiu sensivelmente (convergência sigma). Além disso, a taxa de desemprego caiu entre 1993 e 2008, e o perfil das relações comerciais intrarregionais tornou-se menos assimétrico ao longo de todo o período considerado, ao menos no que se refere à composição das pautas de exportação. Alguns países se destacaram bastante nesse processo, como é o caso da Irlanda - o "tigre celta". ${ }^{12}$

Ademais, de acordo com os indicadores analisados, a Irlanda e os países da Europa meridional apresentaram um melhor desempenho durante a década de 1990, ao passo que as Ilhas Mediterrâneas e os países da Europa oriental saíram-se melhor na década seguinte. Deve-se recordar que a Irlanda fazia parte do bloco desde a década de 1970, ao passo que os países mediterrâneos passaram a integrá-lo na década de 1980. Isso significa que eles passaram pela década de $1990 \mathrm{em}$ condições muito distintas da maioria dos países do leste europeu, que nesse período transitavam de economias centralmente planejadas para economias capitalistas em plena vigência da agenda neoliberal (estabilização, privatização, liberalização e desregulamentação), tendo sido, inclusive, muito afetados pelas crises da Ásia, em 1997, e, principalmente, da Rússia, em 1998.

Por fim, os indicadores apontam também que a crise iniciada em 2007 nos Estados Unidos com graves desdobramentos na União Europeia nos anos seguintes provocou, num primeiro momento, estagnação e, depois, retrocesso nas conquistas de outrora. Embora os 27 países da União Europeia tenham sido afetados,

10 Contudo, deve-se considerar que um crescimento do valor adicionado pela manufatura pode ser acompanhado por um crescimento ainda maior do valor adicionado pelo setor de serviços. Essa, inclusive, é uma possibilidade bastante plausível, dado o desenvolvimento das atividades nas áreas de finanças, transportes, telecomunicações e turismo, entre outras, nos países da União Europeia nos últimos anos.

${ }_{11}$ Vale ressalvar, contudo, que nenhum desses indicadores permite afirmar, com certeza, que houve uma mudança na estrutura produtiva desses países. Sendo assim, a mudança no perfil do comércio intrarregional em favor da periferia deve ser analisada com cautela. Novos estudos sobre o tema são ainda necessários.

12 Até pouco tempo atrás, a Irlanda era um país pastoril, incapaz de concorrer com o Reino Unido, do qual se tornou independente no início do século XX. A Irlanda lembrava, sob muitos aspectos, os países mediterrâneos, a não ser pelo fato de que não havia passado por um regime autoritário, como no Portugal de Antônio Salazar, na Espanha de Francisco Franco e na Grécia de Georgios Papadopoulos. 
foram as economias da periferia do bloco as mais penalizadas, como demonstram os comportamentos da renda per capita e da taxa de desemprego em 2010.

\section{Papel e os Limites da Política Regional}

Nessa seção, será enfatizado o papel das políticas e instituições comuns e, em particular, da política regional, no processo de convergência econômica real que, segundo os indicadores selecionados, ocorreu entre os países europeus nas últimas duas décadas. Serão considerados também os limites que se impõem a essas iniciativas, sobretudo em função do regime de política macroeconômica que prevalece na União Europeia e, em especial, na zona do euro.

\subsection{O Papel da Política Regional}

Tal como apontado pelas teorias alternativas à abordagem convencional, um projeto de integração regional é incapaz de reduzir as assimetrias entre o centro e a periferia quando liderado exclusivamente pelas forças de mercado. A superação do atraso econômico e social dos países da periferia pressupõe a superação das estruturas que caracterizam o subdesenvolvimento. No entanto, as exigências desse processo são expressivas. Nesse caso, um projeto de integração regional não deve se limitar à abertura das fronteiras entre os países participantes, mas viabilizar a criação de políticas e instituições comuns capazes de complementar e, assim, potencializar a ação das políticas e instituições dos países da periferia. Uma vez que essas políticas e instituições comuns são financiadas por meio de um orçamento comum, para o qual contribuem proporcionalmente mais os países mais ricos, elas acabam por constituir um poderoso mecanismo de redistribuição da riqueza.

Os europeus foram os primeiros a criar instrumentos dessa natureza para assegurar a constituição de um espaço relativamente coeso. Entretanto, embora não se possa atribuir a eles a responsabilidade exclusiva pelo processo de convergência que aparentemente ocorreu entre os países europeus nas últimas duas décadas, é provável que tenham desempenhado aí um papel relevante. Um exemplo disso é a política regional da União Europeia. O objetivo é assegurar que os benefícios do processo de integração regional sejam repartidos igualmente entre os países europeus, evitando que estes se concentrarem na Europa setentrional e, especialmente, na região entre Londres, no Reino Unido, Paris, na França, Milão, na Itália, e Munique e Hamburgo, na Alemanha - o chamado pentágono (COMISSÃO EUROPEIA, 2008).

Formalmente criada em 1988, a política regional substituiu uma série de iniciativas esparsas e pouco articuladas que existiam até então. Ela tem seu modus operandi definido por quatro princípios fundamentais: 
a) princípio da programação: a política regional deve financiar programas plurianuais (isto é, conjuntos de ações consideradas relevantes para o desenvolvimento de determinada região e/ou país membro). As autoridades regionais e nacionais devem elaborar os programas e submetê-los às autoridades supranacionais, as quais devem decidir quais programas deverão receber os recursos comunitários;

b) princípio da concentração: serão priorizados os programas que beneficiem as regiões mais pobres e que atendam às prioridades definidas periodicamente pela comunidade;

c) princípio da parceria: não apenas as autoridades regionais, nacionais e supranacionais, mas também todos os setores da sociedade devem trabalhar em conjunto para que os recursos comunitários sejam despendidos da forma acordada e produzam os resultados esperados; e

d) princípio da adicionalidade: a política regional deve complementar, e não substituir, as ações dos países membros em prol do desenvolvimento regional e nacional.

Ao longo das duas últimas décadas, aproximadamente um terço do orçamento da União Europeia destinou-se ao abastecimento dos fundos estruturais e do fundo de coesão, os principais instrumentos da política regional. ${ }^{13} \mathrm{O}$ Gráfico 5 demonstra a evolução da despesa com a política regional entre 1989 e 2013, em termos absolutos e em relação ao PIB. Esses valores são definidos pelas autoridades europeias em encontros realizados periodicamente. Efetivamente, o volume de recursos alocados em termos absolutos cresceu à medida que o projeto de integração europeu tornou-se mais complexo e passou a contar com um número cada vez maior de países. Em 2013, o valor será praticamente cinco vezes superior ao de 1989. Nota-se, entretanto, que o volume de recursos destinados à política regional poderia ter sido ainda maior se tivesse acompanhado o crescimento do PIB da União Europeia nos últimos anos. Isso deixou de ocorrer a partir de 1999.

Nas últimas duas décadas, os maiores beneficiados pela política regional foram a Irlanda e os países da Europa meridional, seguidos pelos países da Europa oriental. Entre os países da Europa setentrional beneficiados, destacam-se aqueles com grandes desigualdades internas. Esse é o caso da Itália (região do Mezzogiorno), do Reino Unido (regiões no noroeste da Inglaterra, Escócia, País de Gales e Irlanda do Norte) e da Alemanha (regiões da ex-Alemanha Oriental) (COMISSÃO EUROPEIA, 2010, 2007, 2004, 2001, 1996).

13 É importante lembrar que a política regional pode contar com o reforço do Banco Europeu de Investimentos (BEI). Criada em 1957 pelo Tratado de Roma, essa instituição comum é responsável pela concessão de empréstimos em condições bastante favoráveis em termos de taxas de juros e prazos de pagamento. O BEI financiou vários programas com recursos captados a baixo custo junto ao mercado, por meio da emissão de títulos de rating elevado (AAA). Isso significa que suas operações independem do orçamento europeu (EL-AGRAA, 2011). 
Em todos esses países, a política regional patrocinou ações nas seguintes áreas:

a) infraestrutura: apoio à expansão das redes de transportes (o que inclui as vias, como estradas, ferrovias e hidrovias, e os terminais, como estações, portos e aeroportos), telecomunicações (redes de telefonia e internet), energia (combustiveis e geração e distribuição de energia elétrica) e saneamento básico (tratamento de água e esgoto);

b) investimento produtivo: apoio à aquisição de máquinas e equipamentos;

c) emprego e inclusão social: apoio ao ingresso de jovens, mulheres, portadores de deficiência, migrantes, estrangeiros e minorias étnicas no mercado de trabalho;

d) educação e treinamento: apoio à qualificação da mão de obra por meio da modernização das instituições e dos sistemas de ensino (básico, superior e profissionalizante);

e) pesquisa e inovação: estímulo às atividades de pesquisa e desenvolvimento (PED) nas empresas e centros de competência;

f) pequenas e médias empresas: apoio ao empreendedorismo local;

g) meio ambiente: estímulo à criação e implementação de fontes alternativas de energia, ao aumento da eficiência energética, ao tratamento de resíduos decorrentes da atividade econômica, à recuperação de áreas degradadas e à proteção de áreas naturais remanescentes;

h) cultura e turismo: apoio à conservação dos patrimônios histórico e cultural europeus;

i) desenvolvimento de áreas rurais: modernização e diversificação das atividades agrícola e pecuária mediante estímulo à criação e implementação de novas técnicas que aumentem o valor da produção;

j) desenvolvimento de áreas urbanas: apoio à recuperação dos centros degradados e à melhoria de certos serviços públicos, como transporte coletivo (ônibus, bondes, metrô e trens urbanos) e habitação; e

k) desenvolvimento institucional: fortalecimento das instituições no que se refere à sua capacidade de prestar serviços e formular e executar políticas públicas (COMISSÃO EUROPEIA, 2010, 2007, 2004, 2001, 1996; TONDL, 2001b). 
Gráfico 5 - Despesa com a política regional (milhões de euros e \% do PIB da União

Europeia): 1989 a 2013

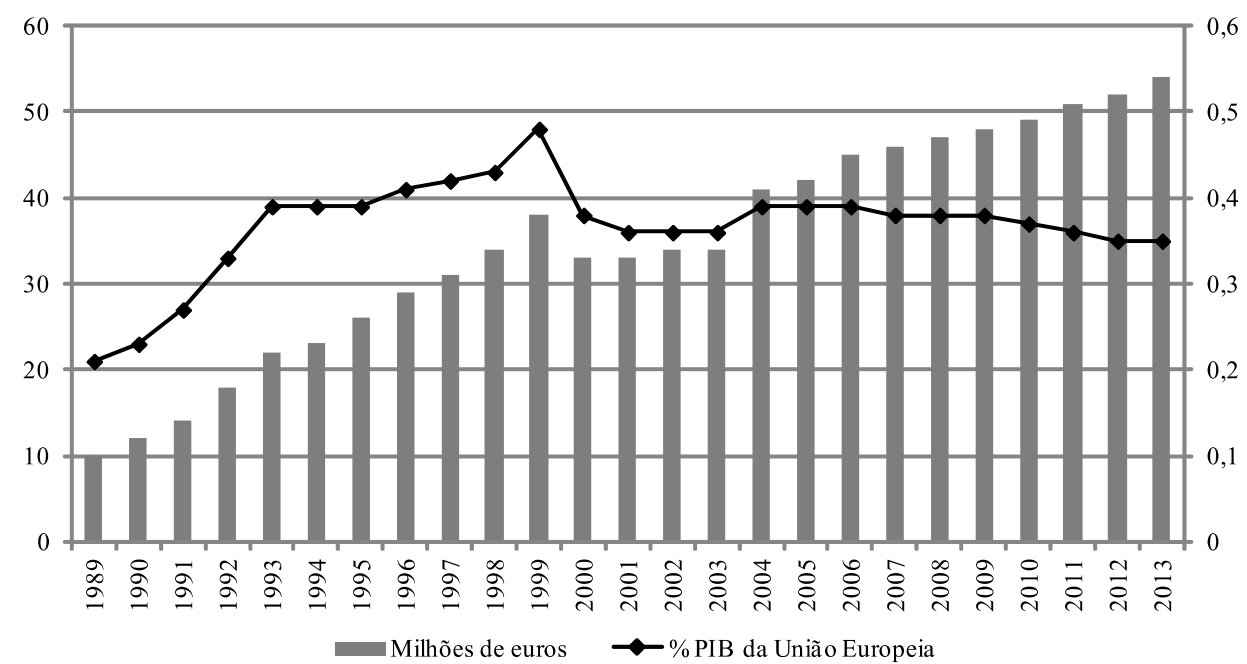

Fonte: Comissão Europeia (2008).

Para Bruxelas, essas ações deveriam agir em duas frentes: do lado da demanda (efeitos de curto prazo) e do lado da oferta (efeitos de longo prazo). Os efeitos de curto prazo surgiriam durante a fase de execução dos programas. Os efeitos de longo prazo, por sua vez, surgiriam depois da conclusão dos programas: as transformações econômicas, sociais e até mesmo políticas viabilizadas por essas ações tornariam as regiões mais pobres mais competitivas (TONDL, 2001b). Diversos estudos foram realizados nas últimas décadas com o intuito de captar a intensidade desses efeitos. Alguns deles foram desenvolvidos pela própria Comissão Europeia, por meio dos modelos Hermin e Quest, por exemplo, que buscam estimar qual foi o impacto macroeconômico das ações patrocinadas pela política regional sobre o crescimento dos países e regiões beneficiados. Nos períodos considerados pela instituição (1989 a 1993, 1994 a 1999 e 2000 a 2006), esses modelos apontaram um efeito positivo dos fundos estruturais e de coesão sobre o produto, a renda e o emprego na maioria dos países considerados (em especial, Irlanda, Grécia, Espanha e Portugal). Isso quer dizer que existem indícios estatísticos de que o desempenho dessas variáveis foi mais favorável do que teria sido caso os investimentos viabilizados pela política regional não tivessem ocorrido. ${ }^{14}$

De fato, muitas regiões europeias se tornaram mais atrativas para as empresas estrangeiras a partir das transformações viabilizadas pela política regional. Em muitos casos, a entrada dessas empresas catalisou o processo de desenvolvimen-

$14 \quad$ Os resultados dos modelos Hermin e Quest para os períodos de 1989 a 1993, 1994 a 1999 e 2000 a 2006, bem como a descrição dos principais avanços viabilizados pela política regional estão disponíveis em Comissão Europeia (2010, 2007, 2004, 2001, 1996). 
to em curso nessas regiões, contribuindo para o aumento da renda per capita, a queda do desemprego e, possivelmente, a mudança da estrutura produtiva. ${ }^{15} \mathrm{~A}$ Tabela 2 apresenta a evolução do estoque de investimento direto estrangeiro (IDE) recebido por cada país membro da União Europeia em relação ao seu PIB, entre 1993 e 2010.

Tabela 2 - Estoque de IDE recebido (\% do PIB): 1993 a 2010 (anos selecionados)

\begin{tabular}{|c|c|c|c|c|c|c|}
\hline Regiões/Países & 1993 & 1996 & 2000 & 2004 & 2008 & 2010 \\
\hline \multicolumn{7}{|c|}{ Europa Setentrional } \\
\hline Alemanha & 5,79 & 6,67 & 14,4 & 18,78 & 18,43 & 21,68 \\
\hline Áustria & 6,4 & 8,4 & 16,2 & 24,3 & 35,8 & 42,5 \\
\hline Bélgica e Luxemburgo & 42,48 & 44,92 & 83,9 & 339,1 & 374,94 & 495,65 \\
\hline Dinamarca & 10,39 & 12,11 & 45,96 & 47,65 & 44,92 & 46,11 \\
\hline Finlândia & 4,83 & 6,86 & 19,93 & 30,35 & 30,71 & 36,61 \\
\hline França & 10,39 & 19,96 & 29,42 & 42,12 & 31,87 & 40,99 \\
\hline Itália & 5,26 & 5,89 & 11,1 & 13,36 & 14,21 & 15,95 \\
\hline Países Baixos & 22,74 & 30,74 & 63,3 & 85,18 & 74,14 & 75,07 \\
\hline Reino Unido & 18,27 & 18,75 & 31,39 & 33,7 & 36,34 & 51,31 \\
\hline Suécia & 6,5 & 12,6 & 37,93 & 54,59 & 57,35 & 74,97 \\
\hline \multicolumn{7}{|c|}{ Europa Meridional + Irlanda } \\
\hline Espanha & 15,75 & 17,91 & 26,94 & 39,01 & 36,96 & 45,23 \\
\hline Grécia & 8,61 & 8,71 & 11,21 & 12,49 & 11,17 & 11,63 \\
\hline Irlanda & 81,53 & 63,07 & 130,41 & 111,34 & 71,86 & 137,79 \\
\hline Portugal & 17,52 & 17,43 & 27,32 & 36,12 & 39,68 & 48,84 \\
\hline \multicolumn{7}{|c|}{ Europa Oriental + Ilhas Mediterrâneas (Chipre e Malta) } \\
\hline Bulgária & 2,26 & 5,48 & 20,95 & 39,98 & 85,02 & 98,96 \\
\hline Eslováquia & 4,76 & 9,67 & 34,16 & 66,83 & 53,48 & 57,75 \\
\hline Eslovênia & 14,57 & 9,45 & 14,48 & 22,43 & 28,66 & 30,68 \\
\hline Estônia & 6,08 & 17,36 & 46,57 & 83,49 & 68,99 & 87,96 \\
\hline Hungria & 14,16 & 28,92 & 49,3 & 60,4 & 57,06 & 70,83 \\
\hline Letônia & 4,78 & 16,53 & 26,8 & 32,97 & 34,49 & 44,61 \\
\hline Lituânia & 1,96 & 8,31 & 20,3 & 28,2 & 27,27 & 36,28 \\
\hline Polônia & 2,45 & 7,32 & 19,98 & 34,32 & 31,04 & 45,9 \\
\hline República Tcheca & 8,72 & 13,21 & 36,81 & 50,24 & 50,2 & 64,59 \\
\hline Romênia & 0,77 & 2,97 & 18,64 & 27,03 & 33,23 & 42,73 \\
\hline Chipre & - & 3,27 & 31,02 & 54,35 & 66,33 & 75,83 \\
\hline Malta & 24,04 & 22,99 & 57,19 & 71,96 & 90,91 & 200,12 \\
\hline
\end{tabular}

Fonte: Elaboração própria a partir de United Nations Conference on Trade and Development (2013). Nota: Dados não disponíveis para Chipre em 1993.

Houve um aumento expressivo do IDE para os países europeus nas últimas duas décadas. Esse aumento se insere em uma tendência mais geral de cresci-

$15 \quad$ Muitos países da Europa meridional (mais a Irlanda) e, principalmente, da Europa oriental (mais Chipre e Malta) receberam empresas da Europa setentrional, sobretudo da Alemanha, França, Itália e Reino Unido, e dos Estados Unidos e de alguns países asiáticos, como China, Coreia do Sul e Japão. O que se espera é que as empresas atuem em setores até então pouco explorados nos países da periferia e, dessa forma, contribuam para o desenvolvimento das estruturas produtivas desses países, o que inclui o aumento da importância relativa das atividades mais sofisticadas, intensivas em conhecimento e tecnologia, capazes de gerar mais produto e renda, além de mais e melhores empregos (AKYÜZ, 2005). Para isso, entretanto, os países da periferia devem oferecer a essas empresas mais que um grande mercado ou abundância de recursos naturais: devem oferecer infraestrutura moderna e integrada, além de mão de obra altamente qualificada, por exemplo. Nesse caso, a política regional pode fazer a diferença. 
mento em nível global, em especial nas décadas de 1980 e 1990, como demonstra Silva (2006). Como exemplo, o IDE global cresceu de US $\$ 53,7$ bilhões, em 1985, para US\$ 196 bilhões, em 1989, e de US $\$ 243$ bilhões, em 1990, para cerca de US\$ 1,2 trilhão em 2000. Isso se deve, entre outros motivos, à liberalização das contas de capital do balanço de pagamentos, ao comportamento das taxas de câmbio e de juros e ao desenvolvimento de novos instrumentos financeiros, que facilitaram a captação de recursos pelas empresas estrangeiras. No caso europeu, é bem provável que esses fluxos tenham sido particularmente estimulados pelo mercado único e pela criação da moeda comum. Destaca-se também o incentivo ao IDE intrarregional e à "formação e fortalecimento de empresas pan-europeias" pelas autoridades da região, com o objetivo de criar "líderes regionais" (SILVA, 2006). ${ }^{16}$

Vale observar que existe, na União Europeia, uma forte relação entre o aumento do IDE e a mudança no perfil das relações comerciais intrarregionais no que se refere à composição das pautas de exportação dos países membros. Essa relação é particularmente evidente no caso da Irlanda e dos países da Europa meridional, bem como das Ilhas Mediterrâneas e dos países da Europa oriental. ${ }^{17}$ Isso poderia ser um indício importante de que as empresas estrangeiras podem ter contribuído para o aparente desenvolvimento das estruturas produtivas dos países da periferia do bloco. ${ }^{18}$

Essa hipótese deve ser qualificada, entretanto. Isso porque as estatísticas sobre comércio internacional, que mostram uma rápida expansão das exportações de alto valor agregado dos países da União Europeia que receberam volume de IDE expressivo, podem ser enganosas ao contabilizarem o comércio entre os países ligados pelas redes internacionais de produção. Como os fluxos de comércio são medidos em valor bruto e não em valor agregado, no caso dos países que estão apenas operando as linhas de montagem dos produtos, as peças e os componentes importados de maior conteúdo tecnológico são contabilizados entre as

16 Destaca-se, ainda, a natureza pró-cíclica do IDE, uma vez que houve desaceleração do crescimento desses fluxos nos períodos de recessão global, notavelmente, entre 1981 e 1983, 1991 e 1993 e 2001 e 2003. Segundo Silva (2006), entre o imediato pós-guerra e a década de 1980 a forma dominante de IDE era a instalação de novas plantas, sobretudo no setor industrial. A partir da década de 1980, passaram as ser dominantes as operações de fusões e aquisições, sobretudo no setor de serviços (atividades nas áreas de finanças, transportes, telecomunicações e turismo).

17 Como demonstra a comparação entre as Tabelas 1 e 2.

18 O caso da Irlanda é emblemático. Ao longo das duas últimas décadas (até o advento da crise da zona do euro), o país experimentou extraordinário crescimento da renda per capita, queda da taxa de desemprego e aumento de produtos de alto valor agregado em sua pauta de exportações. Isso se deve, em grande medida, a uma política agressiva de "industrialização a convite". Além de uma série de incentivos, o governo irlandês criou instituições responsáveis por promover o país no exterior e definir que setores deveriam ser desenvolvidos, que empresas deveriam ser atraídas e que ações deveriam ser patrocinadas, inclusive por meio da política regional, para que o país pudesse se desenvolver. Dentre essas instituições, destaca-se a chamada Industrial Development Agency Ireland, criada em 1994. Graças a esse empenho, o país rapidamente se tornou uma plataforma de exportação para os demais países da União Europeia, sobretudo de empresas norte-americanas (TONDL, 2001b). 
suas exportações, o que distorce o indicador (AKYÜZ, 2005). Como visto, existem indícios de que esse não foi o caso da maioria dos países europeus, uma vez que grande parte daqueles que apresentaram um aumento da participação dos produtos de alto valor agregado na pauta de exportação apresentaram um aumento do valor adicionado pela manufatura em relação ao valor adicionado total pela economia.

\subsection{Os Limites da Política Regional}

Não obstante as tendências positivas captadas pelos indicadores selecionados, deve-se reconhecer que o impacto da política regional foi menor do que poderia ter sido. Há algumas razões para isso. Em primeiro lugar, o volume de recursos destinados ao financiamento dos programas selecionados poderia ser ainda maior, se consideradas as desigualdades socioeconômicas entre as regiões e países que compõem a União Europeia e as transformações necessárias para que haja convergência entre eles. Como visto, esse volume de recursos não acompanhou sequer o crescimento do PIB do bloco nos últimos anos. Em segundo lugar, o princípio da adicionalidade segundo o qual a política regional deve complementar e não substituir as iniciativas dos países europeus em favor do crescimento - não é cumprido como deveria. Isso se deve, em grande medida, aos limites impostos pelo regime de política macroeconômica vigente no âmbito do projeto de integração regional. De fato, esse regime impede que a política macroeconômica seja capaz de contribuir para a redução das assimetrias entre os países europeus, inclusive em ambientes caracterizados por alta incerteza, expectativas pessimistas e elevado grau de preferência pela liquidez.

Ao avançar em direção à união monetária, os países europeus confiaram suas políticas monetária e cambial ao Banco Central Europeu e sujeitaram sua política fiscal às regras do Pacto de Estabilidade e Crescimento. Com isso, eles renunciaram ao controle sobre a política macroeconômica em favor de um arranjo institucional cuja preocupação central corresponde à convergência de variáveis nominais, tais como a taxa de inflação, a taxa de juros, a taxa de câmbio, o déficit público e a dívida pública. Tal arranjo está baseado na hipótese de que a política macroeconômica é incapaz de afetar as variáveis reais, notadamente o produto e a renda, de forma permanente e que o nível de desemprego será tanto menor quanto mais flexível for o mercado de trabalho. ${ }^{19}$

Na há dúvidas de que esse arranjo logrou promover a convergência de variáveis nominais, processo que contribuiu para a convergência das variáveis reais

\footnotetext{
19 "It is assumed that the private sector is stable in the long run and that discretionary economic policies have a destabilizing effect. Inflation is a monetary phenomenon and the central bank can bring down inflation without any real costs in terms of growth or employment. Unemployment fluctuates around an equilibrium level determined by supply-side factors [...] and can only be reduced by creating more flexible labour markets. Fiscal policy has no long-term effect on growth and employment and should be subordinated to the goal of price level stability." (ARESTIS; MCCAULEY; SAWYER, 2000).
} 
entre os países que adotaram o euro na última década. A rápida convergência das taxas de juros particularmente constituiu um poderoso incentivo ao consumo e ao investimento nos países da zona do euro, sobretudo nas economias da periferia da região. Ocorre, porém, que esse processo não era duradouro, em especial em contextos de crise, porque não refletia as assimetrias econômicas, sociais e até mesmo políticas que ainda existiam entre o centro e a periferia europeias. Ao contrário do que esse processo poderia sugerir, não havia na Europa um único euro, mas vários, com diferentes gradientes de risco. Isso ficou evidente a partir de 2008, quando da ocorrência do abrupto descolamento entre as taxas de juros de diversas economias da região, destacadamente entre as taxas de juros dos PIIGS (Portugal, Irlanda, Itália, Grécia, e Espanha), e as taxas de juros da Alemanha, como mostra o Gráfico 6.

Gráfico 6 - Taxa de juros de curto prazo (zona do euro) e de longo prazo

(Alemanha e PIIGS) (\% a.a): 1999 a 2011 (média trimestral)

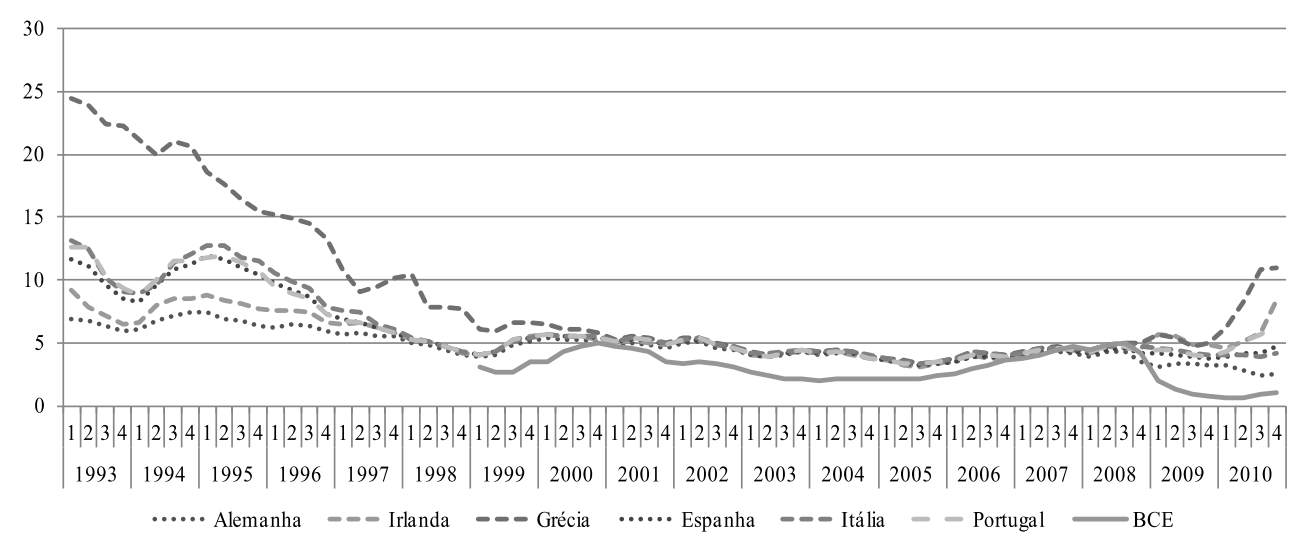

Fonte: Elaboração própria a partir de OCDE (2013) e Eurostat (2013).

Nota: Taxa de juros de curto prazo para zona do euro disponível a partir do primeiro trimestre de 1999.

Além disso, durante o período de prosperidade, a moeda comum permitiu aos países da periferia a ampliação do endividamento, beneficiando-se da expansão de crédito em condições bastante favoráveis, patrocinada pelos países centrais. Quando a liquidez cessou e as taxas de juros aumentaram diante do aprofundamento e da irradiação da crise nos Estados Unidos, verificou-se um clássico processo de desalavancagem, obrigando os governos a agir para evitar a paralisação da economia. O aumento dos gastos orientados para a contenção da crise e a redução das suas receitas, por sua vez, levou à elevação dos déficits públicos e das dívidas públicas de diversas economias da zona do euro, até então relativamente controlados, para além dos limites considerados aceitáveis pelos mercados financeiros. Estes, por seu turno, passaram a exigir dos governos a redução imediata dos gastos públicos, ou seja, o compromisso com a austeridade. A contrapartida do processo de desalavancagem, dessa forma, consistiu na expressiva deteriora- 
ção fiscal dessas economias. Isso ajuda a explicar por que o processo de redução das desigualdades existentes entre a Europa setentrional, meridional e oriental foi abruptamente interrompido a partir de 2008.

Nesse contexto, a Alemanha teria um importante papel a cumprir para a sustentação do processo de convergência, desde que assumisse de forma mais contundente as funções que lhe caberiam enquanto potência regional, qual seja, a de emprestador e comprador de última instância, nos termos de Kindleberger (1986). A função de emprestador de última instância se refere à possibilidade de assegurar a provisão de liquidez quando esta se fizer necessária nos demais países do bloco ou viabilizar atuações nesse sentido por parte de outras instituições europeias, como é o caso do Banco Central Europeu. O objetivo, com isso, seria evitar a propagação de uma eventual crise de liquidez (o efeito contágio) e, no limite, o colapso do sistema bancário e do crédito na Europa. Além disso, se, nesse processo, fosse assegurada a liquidez dos títulos soberanos, isto é, se nessas operações fosse incluída a aceitação de títulos de graus variados de risco, incluindo aqueles que não mais possuem grau de investimento, seria possível evitar a queda dos preços dos papéis dos governos dos países mais endividados da zona do euro. Isso poderia evitar uma elevação do custo da dívida para esses países e, consequentemente, o crescimento do risco de um default em série na região, com consequências sistêmicas potencialmente graves.

Já no que se refere à função de comprador de última instância, o objetivo consiste em assegurar uma fonte estável de demanda, sobretudo para os produtos dos países da periferia. O Gráfico 7 mostra que, atuando em sentido contrário, praticamente nenhum país da União Europeia é mais beneficiado pelo comércio intrarregional que a Alemanha: o país vendeu para os seus vizinhos muito mais do que comprou deles durante todo o período considerado. Efetivamente, os alemães foram muito beneficiados pelo ingresso dos países da Europa oriental na União Europeia, uma vez que tal evento representou um crescimento expressivo do mercado consumidor, mas não da concorrência para os seus produtos - os países do leste europeu, afinal, são uma ameaça para a Irlanda e para os países da Europa meridional, e não para a maioria dos países da Europa setentrional. ${ }^{20}$ Deve-se observar, ademais, que mesmo depois da crise, a Alemanha continuou apresentando superávits comerciais elevados em relação aos demais países da região.

$20 \quad$ Nota-se que apenas os Países Baixos apresentaram superávits tão grandes quanto os da Alemanha. O país funciona como um centro de distribuição de mercadorias para os países da Europa, uma vez que abriga o maior porto marítimo do continente, o de Roterdã. 
Gráfico 7 - Saldo comercial em relação a UE(27) (bilhões de US\$) - 1992 a 2010

(anos selecionados)

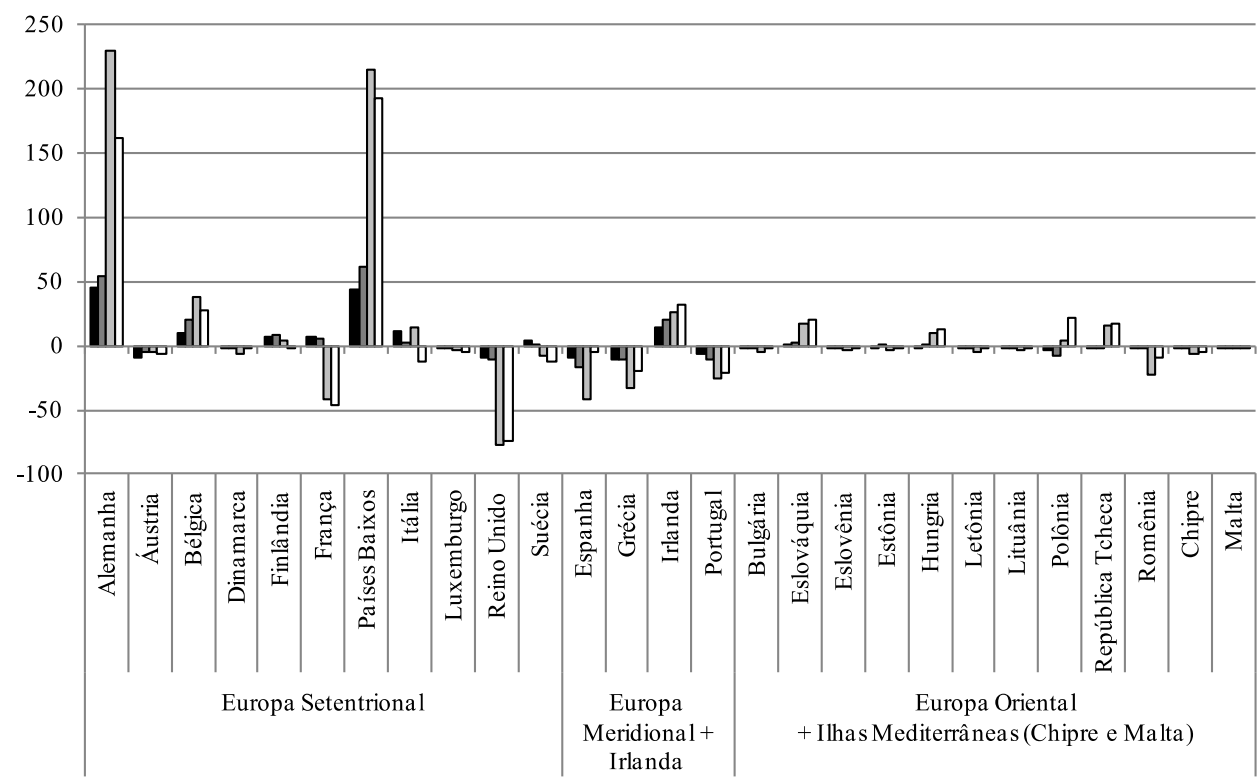

—1995 2000 2008 2010

Fonte: Elaboração própria a partir de United Nations Conference on Trade and Development (2013). Nota: Luxemburgo foi excluído pelo seu tamanho reduzido.

Nas últimas duas décadas, os custos nos países da periferia cresceram mais rapidamente que a produtividade, o que não aconteceu em outros países do centro e, em particular, na Alemanha. Isso fez com que esses países perdessem competitividade em relação aos seus vizinhos. Na impossibilidade se recorrer à desvalorização das taxas de câmbio, esses países passaram a apresentar déficits elevados na balança comercial e, também, em transações correntes. A princípio, esses déficits implicavam apenas um vazamento de demanda para o exterior. Não havia um problema de financiamento, uma vez que os capitais fluíam do centro para a periferia como nunca haviam feito antes. Quando a entrada de capitais diminuiu diante do aprofundamento da crise, entretanto, os países da periferia foram obrigados a recorrer ao ajuste recessivo do balanço de pagamentos, isto é, via redução de preços e salários - o ajuste deflacionário. A questão é que a desaceleração das demais economias da União Europeia, em geral, e da zona do euro, em particular, poderá afetar de forma adversa as exportações da Alemanha, as quais constituem o motor propulsor de sua economia.

A crítica que se faz aqui é muito semelhante àquela que Keynes fez ao mecanismo de ajuste do balanço de pagamentos no âmbito do padrão-ouro. Segundo as regras desse sistema monetário, a entrada e a saída de reservas internacionais, a saber, o ouro, condicionava a oferta interna de moeda e, portanto, a taxa de juros. 
Países com déficit no balanço de pagamentos experimentavam uma saída líquida de ouro, o que levava automaticamente a uma redução da oferta interna de moeda e a um aumento da taxa de juros. A queda da atividade econômica e a redução de preços e salários decorrentes restauravam a competitividade do país e, assim, o equilíbrio das contas externas. No âmbito das discussões sobre a criação de um novo sistema monetário internacional que levariam aos acordos de Bretton Woods, Keynes alertou para o fato de que, nos limites impostos pelo padrão-ouro, todo esforço de ajuste do balanço de pagamentos recaia necessária e invariavelmente sobre os países deficitários na forma de um ajuste deflacionário muito semelhante àquele praticado pelos países da periferia da zona do euro hoje em dia. Nessas circunstâncias, o ideal, segundo ele, seria que também os países superavitários fizessem a sua parte. Uma vez que o custo de um ajuste recessivo seria muito superior ao de um ajuste expansionista, a reciprocidade no processo de ajustamento do balanço de pagamentos seria a melhor opção para todos (FERRARI FILHO, 2006).

\section{Considerações Finais}

Ao mesmo tempo em que se tornava mais profundo, o projeto de integração regional europeu passou a contar com um número cada vez maior de países participantes. Essa expansão foi e ainda é extremamente complexa, porque envolve economias muito diferentes do ponto de vista econômico-estrutural. Nesse sentido, o objetivo deste trabalho foi verificar se existem indícios de que o aprofundamento do processo de integração regional foi acompanhado por uma redução das desigualdades socioeconômicas existentes entre os países europeus. A análise indicou que a renda per capita dos países mais pobres cresceu mais rapidamente que a dos países mais ricos, e que a variabilidade das rendas per capita de todos os países da União Europeia diminuiu sensivelmente entre 1993 e 2008. Nesse mesmo período, as taxas de desemprego se reduziram e o perfil das relações comerciais intrarregionais tornou-se menos assimétrico. Em resumo, houve indícios de convergência econômica real entre eles.

Argumentou-se que um projeto de integração regional não deve se restringir à eliminação das fronteiras nacionais aos fluxos de mercadorias, serviços, pessoas e capitais entre os países participantes e que a criação de políticas e instituições comuns é uma forma de auxiliar os países da periferia a superar as estruturas que caracterizam o subdesenvolvimento. Exemplo disso é a política regional da União Europeia. Por meio dos fundos estruturais e de coesão, cujos recursos provêm do orçamento comunitário, ela patrocinou ações importantes, as quais, inclusive, contribuíram para a atração de empresas estrangeiras para as regiões mais pobres do bloco. 
Entretanto, desde que os países europeus renunciaram ao controle sobre as políticas monetária, cambial e fiscal em favor de um arranjo institucional cuja orientação se restringe à convergência de variáveis nominais (como visto, as taxas de inflação, de juros e de câmbio, além do déficit público e da dívida pública), a política macroeconômica não é capaz de contribuir para a redução das assimetrias existentes entre eles. Isso se tornou particularmente evidente durante a crise europeia, o que ajuda a explicar por que o processo de redução das desigualdades existentes entre os países europeus foi abruptamente interrompido a partir de 2008.

Nesse contexto, caberia à Alemanha assumir de forma mais contundente as funções de emprestador e comprador de última instância. Mas não foi isso o que se observou nas últimas duas décadas, incluindo o período da crise. De um lado, os alemães mostraram-se relutantes em assegurar a provisão de liquidez quando essa liquidez se fez necessária nos demais países do bloco, ou, ainda, em viabilizar atuações nesse sentido por parte de outras instituições europeias. De outro lado, resistiram em aumentar as suas importações e, assim, em reduzir os elevados superávits comerciais que mantêm em relação aos demais países da região, o que estimularia essas economias e evitaria que o peso do ajuste dos desequilíbrios nas contas externas, que tão frequentemente as caracterizam, recaísse inteiramente sobre elas. Não bastasse isso, a desaceleração das demais economias da União Europeia, em geral, e da zona do euro, em particular, pode afetar de forma adversa as exportações da própria Alemanha, as quais constituem o motor propulsor de sua economia.

Vale mencionar, ainda, que a política regional cumpriu papel importante no processo de convergência real verificado entre 1993 e 2008 na União Europeia. Contudo, o regime de política macroeconômica dos países da região, destacadamente daqueles que formam o bloco da zona do euro, embora tenha contribuído para esse processo de convergência durante o período de prosperidade, inviabilizou, juntamente com a posição assumida pela Alemanha na região, a atenuação dos retrocessos observados a partir da crise de 2008. A impossibilidade de realização de políticas econômicas autônomas por parte dos países da zona do euro pode, inclusive, comprometer todos os avanços conquistados pelos países da região em termos de convergência real.

Assim, a despeito dos problemas e das imperfeições existentes na experiência europeia de integração regional, esse processo evidenciou a importância das políticas e instituições comuns para viabilizar e/ou intensificar os potenciais benefícios decorrentes de um projeto de integração. Porém, a experiência em tela também revela que um projeto de integração não pode ser assentado em convergência nominal condicionada por fluxos voláteis de capitais privados. De qualquer modo, embora ainda com fragilidades importantes, a experiência europeia demonstra que a transformação de um projeto de integração regional, efetivamente, em um 
aliado no esforço de redução das desigualdades socioeconômicas existentes entre os países participantes requer instituições e políticas supranacionais efetivas.

\section{Referências}

AKYÜZ, Y. Impasses do desenvolvimento. Novos Estudos Cebrap, São Paulo, n. 72, p.41-56, 2005.

AMADO, A. M. Moeda, financiamento, sistema financeiro e trajetórias de desenvolvimento regional desigual: a perspectiva pós-keynesiana. Revista Economia Política, v. 18, n. 1(69), p. 76-89, jan.-mar. 1998.

AMADO, A. M.; SILVA, L. A. S. Considerações sobre as perspectivas Nacionais e Regionais do processo de integração regional monetário-financeira do Mercosul. Estudos Econômicos, São Paulo, v. 30, n. 4, p. 571-596, out.-dez. 2000.

AMADO, A. M; MOLLO, M. L. R. Ortodoxia e heterodoxia na discussão sobre integração regional: a origem do pensamento da CEPAL e seus desenvolvimentos posteriores. Estudos Econômicos, São Paulo, v. 34, n. 1, p. 129-156, jan.-mar. 2004.

ARESTIS, P. et al. O euro e a UME: lições para o Mercosul. Economia e Sociedade, Campinas, V. 12, n. 1 (20), p. 1-24, jan./jun. 2003.

ARESTIS, P.; MCCAULEY, K.; SAWYER, M. C. An alternative stability pact for the European Union. Annandale-on-Hudson, NY: The Levy Economics Institute, Mar. 2000. (Working Paper n. 296).

. From the common market to EMU: an historical perspective on European economic and monetary integration. In: ARESTIS, P.; BROWN, A.; SAWYER, M. C. The euro: evolution and prospects. Cheltenham, UK; Northampton, MA: Edward Elgar, 2001a.

. The conditions surrounding the launch of the euro. In: ARESTIS, P.; BROWN, A.; SAWYER, M. C. The euro: evolution and prospects. Cheltenham, UK; Northampton, MA: Edward Elgar, 2001b.

ARESTIS, P.; SAWYER, M. The design faults of the economic and monetary union. Journal of Contemporary European Studies, v. 19, n. 1, p. 21- 32, Mar. 2011.

ARMSTRONG, H.; TAYLOR, J. Regional economics and policy. 3. ed. Oxford, UK: Black-well Publishers, 2000.

BEN-DAVID, D. Equalizing exchange: trade liberalization and income convergence. Quartely Journal of Economics, v. 108, n. 3, p. 653-679, 1993.

BIBOW, J. The euro and its guardian of stability: the fiction and reality of the 10th anniversary blast. Annandale-on-Hudson, NY: The Levy Economics Institute, Nov. 2009. (Working Paper n. 583).

BIELSCHOWSKY, R. (Org.). Cinqüenta anos de pensamento na CEPAL - uma resenha. Rio de Janeiro: Record, 2000.

BITTENCOURT, S. O euro. São Paulo: Publifolha, 2002.

BULMER, S. History and institutions of the European Union In: ARTIS, M. J.; NIXSON, F. I. The economics of the European Union: policy and analysis. 3. ed. Oxford; New York: Oxford University Press, 2001. 
CHICK, V.; DOW, S. C. A post-keynesian perspective on the relation between banking and regional development. In: ARESTIS, P. (Org.). Post-keynesian monetary economics: new approaches to financial modeling. Aldershot: E. Elgar, 1988.

COMISSÃO EUROPEIA. EU Cohesion Policy 1988-2008: investing in Europe's future. Panorama Magazine. Luxembourg, n. 26, p.1-44, June 2008.

Fifth Report on Economic and Social Cohesion. Luxembrurg: Ofiice for Official Publications of the European Communitites, 2010

. First Report on Economic and Social Cohesion. Luxembourg: Office for Official Publications of the European Communities, 1996.

. Fourth Report on Economic and Social Cohesion. Luxembourg: Ofiice for Official Publications of the European Communities, 2007.

. Second Report on Economic and Social Cohesion. Luxembourg: Office for Official Publications of the European Communities, 2001.

.Third Report on Economic and Social Cohesion. Luxembourg: Ofiice for Official Publications of the European Communities, 2004.

DOW, S. C. The regional composition of the money multiplier process. Scottish Journal of Political Economy, v. 29, n. 1, p. 22-44, Feb. 1982.

EICHENGREEN, B. A globalização do capital: uma história do sistema monetário internacional. São Paulo: Ed. 34, 2000.

EL-AGRAA, A. (Ed). The European Union: economics and policies. 9. ed. Cambridge, UK: Cambridge University Press, 2011.

EUROSTAT. Statistics Database: base de dados. Disponível em: <http://epp.eurostat.ec. europa.eu/portal/page/portal/eurostat/home/> . Acesso em: 15 out. 2013.

FERRARI FILHO, F. As propostas keynesianas de reforma do sistema monetário internacional: em busca da neutralidade da moeda de conversibilidade internacional? Revista de Economia, Curitiba, v. 32, n. 2 (ano 30), p. 7-20, jul./dez. 2006.

INTERNATIONAL MONETARY FUND. World Economic Outlook Databases: base de dados. Disponível em: < http://www.imf.org/external/ns/cs.aspx?id=28>. Acesso em: 15 out. 2013.

JONES, C. Introdução à teoria do crescimento econômico. Tradução de Maria José Cyhlar Monteiro. Rio de Janeiro: Campus, 2000.

KINDLEBERGER, C. P. The world in depression: 1929-1939. Revised and enlarged edition. Berkeley: University of California, c1986. 355p.

KRUGMAN, P. About the work. The New York Times, New York, USA, 15 Oct. 2008. Disponivel em: < http://krugman.blogs.nytimes.com/2008/10/15/about-the-work/>. Acesso em: 2 nov. 2011.

Geography and trade. Cambridge, UK: MIT Press, 1991a.

KRUGMAN, P. Increasing returns and economic geography. Journal of Political Economy, v. 99, n. 3, p. 483-499, June 1991b.

. What's new about the new economic geography? Oxford Review of Economic Policy, v. 14, n. 2, p. 7-17, 1998. 
MEDEIROS, C. A. Os dilemas da integração sul-americana. Cadernos do Desenvolvimento, Rio de Janeiro, v. 3, n. 5, p. 213-254, dez. 2008.

OLIVEIRA, G.; DEOS, S. Formação e internacionalização de grandes grupos empresariais: experiências selecionadas da União Europeia. In: DEOS, S.; OLIVEIRA, G. (Org.). Formação e internacionalização de grandes empresas: experiências internacionais selecionadas. São Paulo: Fundap; Campinas: CERI/IE/Unicamp, 2012. 345p.

ORGANISATION FOR ECONOMIC CO-OPERATION AND DEVELOPMENT. StatExtracts: base de dados. Disponível em: < http://www.oecd.org/statistics/> . Acesso em: 15 out. 2013.

RAY, D. Development economics. Princeton, USA: Princeton University Press, 1998.

SALVATORE, D. Introdução à economia internacional. Tradução de Teresa Cristina Padilha de Souza e Eduardo Benedito Curtolo. Rio de Janeiro: LTC, 2007.

SILVA, L. A. Tendências dos fluxos globais de investimento direto externo. Brasília, DF: IPEA, 2006. (Texto para discussão n. 1192).

TONDL, G. Convergence after divergence? Regional growth in Europe. Wien: Springer-Verlag, 2001a.

. Regional Policy. In: ARTIS, M. J.; NIXSON, F. I. The economics of the European Union: policy and analysis. 3. ed. Oxford; New York: Oxford University Press, $2001 \mathrm{~b}$.

UNITED NATIONS CONFERENCE ON TRADE AND DEVELOPMENT. Statistics: base de dados. Disponível em: <http://unctad.org/en/Pages/Statistics.aspx> . Acesso em: 15 out. 2013.

WOLF, P. J. W. Integração regional e convergência econômica: lições da experiência europeia. 2011. 144 f. Monografia (Graduação em Ciências Econômicas) - Instituto de Economia, Universidade Estadual de Campinas, Campinas, 2011.

Recebido em: 31/08/2012.

Aceito em: 05/07/2013. 